\title{
Alterations in the Mitochondrial Proteome of Neuroblastoma Cells in Response to Complex 1 Inhibition
}

\author{
Florence Burté, Luigi A. De Girolamo, Alan J. Hargreaves, and E. Ellen Billett* \\ School of Science and Technology, Nottingham Trent University, Clifton Lane, NG11 8NS Nottingham, U.K. \\ Supporting Information
}

\begin{abstract}
Increasing evidence points to mitochondrial dysfunction in Parkinson's disease (PD) associated with complex I dysfunction, but the exact pathways which lead to cell death have not been resolved. 2D-gel electrophoresis profiles of isolated mitochondria from neuroblastoma cells treated with subcytotoxic concentrations of 1-methyl-4-phenyl-1,2,3,6-tetrahydropyridine (MPTP), a well-characterized complex I inhibitor, were assessed to identify associated targets. Up to 27 differentially expressed proteins were observed, of which 16 were identified using peptide mass fingerprinting. Changes in protein levels were validated by immunoprobing $1 \mathrm{D}$ blots, confirming increases in heat

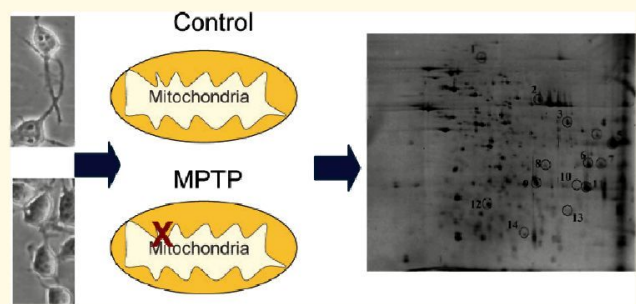
shock cognate $71 \mathrm{kDa}$ (Hsc70), $60 \mathrm{kDa}$ heat shock protein (Hsp60), fumarase, glutamate oxaloacetate transaminase 2, ATP synthase subunit $\mathrm{d}$, and voltage-dependent anion-channel 1 (VDAC1). Immunoprobing of $2 \mathrm{D}$ blots revealed isoform changes in Hsc70, Hsp60, and VDAC1. Subcytotoxic concentrations of MPTP modulated a host of mitochondrial proteins including chaperones, metabolic enzymes, oxidative phosphorylation-related proteins, an inner mitochondrial protein (mitofilin), and an outer mitochondrial membrane protein (VDAC1). Early changes in chaperones suggest a regulated link between complex 1 inhibition and protein folding. VDAC1, a multifunctional protein, may have a key role in signaling between mitochondria and the rest of the cell prior to cell death. Our work provides new important information of relevance to PD.
\end{abstract}

KEYWORDS: Parkinson's disease, mitochondrial dysfunction, MPTP, complex I inhibition, 2DE, mitochondrial proteome, differentially expressed

\section{INTRODUCTION}

Parkinson's disease (PD) is the second most common neurodegenerative condition ${ }^{1}$ affecting 1 to $2 \%$ of the world's population over the age of $60 .^{2}$ It is a progressive neurological movement disorder ${ }^{3}$ characterized by the selective degeneration of dopaminergic neurons, mainly in the substantia nigra pars compacta, ${ }^{4}$ linked with formation of proteinaceous inclusions, commonly known as Lewy bodies. ${ }^{5}$ Current treatments, involving maintenance of dopamine levels, alleviate the symptoms but do not prevent neurodegeneration, ${ }^{6}$ due to the fact that the exact pathways involved in the disease have not been completely resolved. Several hypotheses have been proposed including mitochondrial dysfunction, ${ }^{7}$ protein degradation impairment, ${ }^{8}$ defects in calcium homeostasis, glutamate excitotoxicity, ${ }^{9}$ inflammation, ${ }^{10}$ and oxidative stress. ${ }^{11,12}$ Whether these features are linked, how they lead to neurodegeneration, and which are primary and secondary effects still remain unsolved.

Mitochondrial dysfunction has been observed in both idiopathic and genetic forms of PD. For example, complex I activity of the electron transport chain (ETC) was up to $30 \%$ lower in brain, muscle, and platelets from $P D$ patients ${ }^{13}$ and coenzyme $Q$ 10 , an essential cofactor in the ETC, was decreased in PD patients ${ }^{14}$ both characteristics would lead to increased intracellular oxidative stress, proton gradient impairment, and reduced ATP production. Additionally, DJ-1, PINK1, and the protease Htra2/Omi have all been linked to genetic forms of the disease and are all localized in mitochondria and/or linked to mitochondrial function. ${ }^{15}$ The neurotoxin 1-methyl-4-phenyl-1,2,3,6-tetrahydropyridine (MPTP) was originally observed to reproduce Parkinson's like symptoms in heroin addicts ingesting a synthetic narcotic containing the toxic substance. ${ }^{16}$ It has since been shown that MPTP can be metabolized by monoamine-oxidase (MAO)- $\mathrm{B}^{17}$ into a toxic product, 1-methyl-4-phenylpyrimidium $\left(\mathrm{MPP}^{+}\right)$, which primarily targets nigrostriatal dopaminergic neurons via the dopamine uptake system, leading to inhibition of complex I of the ETC ${ }^{18,19}$ and cell death. MPTP became of particular interest when it was found to reproduce symptomatic, pathological, and biochemical features of PD in animal models ${ }^{20,21}$ and is one of the most commonly used pharmacology-based model of PD, both in vivo and in vitro.

Proteomic approaches of relevance to PD have only emerged in the past decade, mostly concentrating on total cell extracts from a variety of experimental models, models involving both genetic or pharmacologic approaches, in vivo ${ }^{22-25}$ and in vitro. ${ }^{26}$ These include the effects of MPTP or $\mathrm{MPP}^{+}$on mice, using 2Dgel electrophoresis $(2 \mathrm{DE})^{27}$ or shotgun approaches, ${ }^{28,29}$ and on human neuroblastoma cells using $2 \mathrm{DE} .^{30}$ Many of these studies have led to the creation of lists of differentially expressed proteins containing 10-100 identities that do not always agree depending on the model, the approach, and the part of animal brain studied,

Received: December 3, 2010 
and only a few protein changes have been validated in their respective experimental model ( 3 proteins by Zhao et al., ${ }^{27} 1$ by Palacino et al., ${ }^{31}$ and 2 by Xun et al. ${ }^{23}$ ).

Few studies have concentrated on the mitochondrial proteome. Jin and colleagues ${ }^{32}$ isolated mitochondria from the substantia nigra of PD patients, and subjected them to a peptidomic shotgun process, leading to the identification a large number of differentially expressed proteins in PD brains compared to age-matched controls and validated only the decrease in mortalin, confirming its potential role in mitochondrial dysfunction. More recently, Pennington and colleagues ${ }^{33}$ enriched mitochondria from two human SH-SY5Y cell lines overexpressing either wild-type or a mutant $\alpha$-synuclein, the latter shown to be linked to PD pathology. The levels of only 8 proteins changed in the overexpressed mutant model, while the levels of many proteins changed in the cell line overexpressing wild-type $\alpha$ synuclein, of which only $34 \%$ of identified proteins were known to be located in mitochondria, suggesting the presence of a substantial number of nonmitochondrial proteins in the mitochondria-enriched fraction. ${ }^{33}$ There have been very few attempts to study the effects of toxins of relevance to PD specifically on the mitochondrial proteome. A shotgun proteomic approach has been used to analyze proteomic changes in mitochondrial fractions from the subtantia nigra of mice treated with MPTP, identifying up to 110 differentially expressed proteins and validating the change in expression in DJ-1 in both the mouse model and in human substantia nigra from PD patients. ${ }^{34}$ Finally, Jin and colleagues have analyzed mitochondrial proteomes from dopaminergic MES cells treated with cytotoxic concentrations of rotenone leading to $50 \%$ cell death as measured by MTT reduction and Trypan blue exclusion assays. ${ }^{35} \mathrm{~A}$ combination of 1Dgel electrophoresis and liquid chromatography-tandem mass spectrometry (LC-MS) was used to assess the mitochondriaenriched fractions. They identified many differentially expressed proteins ( 110 mitochondrial proteins), probably due to the high level of toxicity, and validated 5 of these changes using Western blotting, being one of the biggest number of validated potential markers up to date.

Although in vivo models allow the study of pathological, behavioral, and symptomatic reactions and are essential for curative treatment trials prior to human testing, ${ }^{36}$ they involve a study of a mixture of cells and the actual concentration of an agent reaching particular neurons is not known. On the other hand, established cell lines are essentially composed of one clonal cell type and they provide a good model for understanding the particular molecular pathways involved in a nonmetabolized treatment in a particular type of cell. ${ }^{37}$ Since the exact pathways involved in cell death following complex I inhibition are still not fully resolved, the present study investigated the effects of MPTP on the mitochondrial proteome. As the mouse model has been widely used for MPTP cytotoxic studies ${ }^{27,38}$ allowing in vitro studies to be compared to in vivo studies, the mouse $\mathrm{N} 2 \mathrm{a}$ neuroblastoma cell line was chosen in the present study. N2a neuroblastoma cell line is an adrenergic clone that shows neuronal morphology characterized by cell bodies with a large number of elongated processes. ${ }^{39}$ The cell line contains high levels of tyrosine hydroxylase and also low levels of dopamine, norepinephrine, serotonin, and $\mathrm{MAO} .^{40}$ Mouse N2a neuroblastoma differentiation has been well-characterized following serum withdrawal and dibutyryl cyclic AMP (dbcAMP) treatment. ${ }^{41,42}$ N2a cells have been used in a wide range of studies including toxicological studies ${ }^{43,44}$ and in vitro models for neurodegenerative diseases such as Alzheimer's disease, ${ }^{45}$ Huntington's disease, ${ }^{46}$ and PD. ${ }^{47,48}$ To identify the pathways occurring early in neurodegeneration and prior to death of N2a cells, it was important to use a subcytotoxic concentration of MPTP in our study. Mitochondria were enriched from $\mathrm{N} 2 \mathrm{a}$ cells using differential centrifugation and the degree of purity of the fraction was extensively analyzed using a combination of enzyme assays (succinate dehydrogenase [SDH], lactate dehydrogenase $[\mathrm{LDH}]$, and NADPH-cytochrome $\mathrm{c}$ reductase as mitochondrial, cytoplasmic, and endoplasmic reticulum markers, respectively) and antibody probing of Western blots to measure the presence of specific marker proteins (cytochrome $\mathrm{c}$, GAPDH, lamin, and LAMP2 as mitochondrial, cytoplasmic, nuclear, and lysosomal markers, respectively).

Numerous proteomic studies carried out in PD research using cell lines have been $2 \mathrm{DE}$ based. ${ }^{26,30,33,35,49}$ By combining 2DE with peptide mass fingerprinting, proteins whose expression levels are altered can be selectively identified. Moreover, different isoforms and post-translationally modified proteins can be more easily distinguished. A 2DE-based proteomic approach was thus chosen to investigate the proteome of isolated mitochondria and to identify proteins affected prior to cell death by mild concentrations of MPTP. The chosen concentration of MPTP reduced ATP levels significantly but did not lead to cell death, according to other markers of toxicity; thus, the aim was to study both the effects of ATP depletion together with the additional consequences of complex I inhibition. Validation of protein changes was then carried using alternative approaches, namely, 1D- and 2D-immunoprobing Western blots.

\section{EXPERIMENTAL SECTION}

\section{Cell Culture and Treatments}

Mouse N2a neuroblastoma cells (ICN, U.K.) were maintained as a monolayer in growth medium containing Dulbeco's modified Eagle's medium (DMEM), 10\% (v/v) fetal bovine serum, $2 \mathrm{mM} 2$-L-glutamine, 100 units $/ \mathrm{mL}$ penicillin and 100 units $/ \mathrm{mL}$ streptomycin (Lonza, U.K.). Cells were incubated and maintained at $60-85 \%$ confluence at $37^{\circ} \mathrm{C}$ in a humidified atmosphere of $95 \%$ air $/ 5 \% \mathrm{CO}_{2}(\mathrm{v} / \mathrm{v})$. For cell differentiation, cells were plated at a density of 20000 cells $/ \mathrm{cm}^{2}$ and allowed to recover for $24 \mathrm{~h}$. The growth medium was then removed and replaced by a differentiating medium containing $0.3 \mathrm{mM}$ dbcAMP (Sigma-Aldrich, U.K.), $2 \mathrm{mM}$ 2-L-glutamine, 100 units $/ \mathrm{mL}$ penicillin and 100 units $/ \mathrm{mL}$ streptomycin in DMEM. Following $16 \mathrm{~h}$ incubation, fresh differentiating medium was added with or without MPTP (0-2 $\mathrm{mM}$; Sigma-Aldrich, U.K.) for a period of $24-48 \mathrm{~h}$. The morphology of cells was recorded using a camera (OLYMPUS DN100 Digital Net Camera, Nikon, Japan) attached to an inverted light microscope (OLYMPUS Nikon Eclipse TS100, Japan) at $400 \times$ magnification.

\section{3-(4,5-Dimethylthiazol-2-yl)-2,5-diphenyltetrazolium Bro-} mide (MTT) Reduction Assay

Cell viability was monitored by measuring cellular metabolic activity in 96-well plates as described by Mosmann. ${ }^{50}$ In brief, following differentiation and treatment of cells (100 $\mu \mathrm{L}$ volume), $10 \mu \mathrm{L}$ of filtered MTT (Sigma-Aldrich, U.K.) solution $(5 \mathrm{mg} / \mathrm{mL}$ ) was added to each well for $1 \mathrm{~h}$. The medium was then carefully removed and $100 \mu \mathrm{L}$ of dimethyl sulphoxide was added to each well. Following gentle agitation, the absorbance was measured at $570 \mathrm{~nm}$. Results were expressed as mean percentage control (untreated cells) cell \pm standard error of the mean (SEM). 
Trypan Blue Exclusion Assay

Cell membrane integrity was measured as described previously ${ }^{42}$ using the Trypan blue exclusion assay. Cell viability was expressed as mean $\%$ viability \pm SEM compared to controls (untreated cells).

\section{ATP Assay}

Cellular ATP was monitored using the Vialight HS kit according to manufacturer's guidelines (Lumitech Ltd., U.K.). Luminescence was read using FLUOStar OPTIMA (BMG Labtech, U.K.) and results were expressed as a mean percentage $\mathrm{ATP} \pm \mathrm{SEM}$ compared to untreated controls.

\section{Mitochondrial Isolation}

All the steps were undertaken on ice. Following differentiation and treatment, cells were harvested and washed several times in $1 \mathrm{~mL}$ of sterile phosphate buffer saline (PBS). The resultant pellet was resuspended in $500 \mu \mathrm{L}$ of extraction buffer (EB) containing $10 \mathrm{mM}$ HEPES, pH 7.5, $70 \mathrm{mM}$ sucrose, $200 \mathrm{mM}$ mannitol, $1 \mathrm{mM}$ EGTA, $1 \%(\mathrm{v} / \mathrm{v})$ protease inhibitor cocktail (Sigma-Aldrich, U.K.) and $1 \%(\mathrm{v} / \mathrm{v})$ phosphatase inhibitor cocktail 2 (Sigma-Aldrich, U.K.), transferred into a Dounce, All-Glass $2 \mathrm{~mL}$ capacity Tissue Grinder (Apollo Scientific, U.K.), and homogenized sequentially by 10 passes with loose fitting and close fitting pestles accompanying the grinder. Differential centrifugation was then carried out following a modified protocol from Lai and Clark ${ }^{51}$ The homogenate was centrifuged at $1000 \mathrm{~g}$ for $10 \mathrm{~min}$ followed by a further $5 \mathrm{~min}$ centrifugation of the resuspended pellet in EB. The resulting pellet was termed the "nuclear-enriched fraction". Supernatants were combined and centrifuged at $10000 \mathrm{~g}$ for $15 \mathrm{~min}$ and the subsequent pellet was further centrifuged at $10000 \mathrm{~g}$ for $10 \mathrm{~min}$ after resuspension in EB. The resulting pellet was termed the "mitochondria-enriched pellet". Supernatants were combined and termed the "cytoplasmic fraction". Fractions were either stored at $-80{ }^{\circ} \mathrm{C}$ or resuspended in $\mathrm{EB}$ for further analysis of purity assessment.

\section{Protein Estimation}

Protein concentration was estimated using the Bio-Rad protein assay kit (Bio-Rad Laboratories Ltd., U.K.) based on the Bradford method, ${ }^{52}$ used in accordance with the manufacturer's instructions.

\section{Succinate Dehydrogenase (SDH) Assay}

$\mathrm{SDH}$ activity was used to assay the presence of mitochondria in various subcellular fractions. Glass test tubes containing $1 \%$ (w/v) iodonitrotetrazolium, $100 \mu \mathrm{L}$ of SDH buffer $(0.25 \mathrm{M}$ sodium phosphate, $5 \mathrm{mg} / \mathrm{mL}$ BSA, pH 7.4), $150 \mu \mathrm{L}$ of distilled water and $50 \mu \mathrm{L}$ of sample were equilibrated in a $37^{\circ} \mathrm{C}$ water bath, $100 \mu \mathrm{L}$ of sodium succinate $(100 \mathrm{mM})$ was added, and tubes were incubated for $1.5 \mathrm{~h}$ at $37^{\circ} \mathrm{C}$. The reaction was stopped by the addition of $500 \mu \mathrm{L}$ of trichloroacetic acid $(10 \%(\mathrm{w} / \mathrm{v}))$. Ethylacetate $(3 \mathrm{~mL})$ was added to each tube and thoroughly mixed. The organic phase was transferred to a polyvinyl chloride 96-well-plate and absorbance read at $490 \mathrm{~nm}$. To check for enrichment, the mean specific activity per microgram protein was normalized against the specific activity of the total extract (given a value of 1) and data were expressed as mean \pm SEM.

\section{Lactate Dehydrogenase (LDH) Assay}

$\mathrm{LDH}$ activity was used as a cytoplasmic marker in each fraction. In a plastic cuvette, $50 \mu \mathrm{L}$ of sodium pyruvate $(27 \mathrm{mM}), 50 \mu \mathrm{L}$ of cellular fraction and $850 \mu \mathrm{L}$ of PBS $(8 \mathrm{~g} / \mathrm{L}$ sodium chloride, $0.2 \mathrm{~g} / \mathrm{L}$ potassium chloride, $1.15 \mathrm{~g} / \mathrm{L}$ sodium dihydrogen orthophosphate, $0.2 \mathrm{~g} / \mathrm{L}$ disodium hydrogen) were added. The reaction was initiated with $50 \mu \mathrm{L}$ of NADH ( $4 \mathrm{mM})$ and absorbance was recorded every $15 \mathrm{~s}$ for 3 min using a spectrophotometer at $340 \mathrm{~nm}$. The mean specific activity per microgram of protein for each fraction was normalized against the specific activity of the total extract (given a value of 1 ) and data were expressed as mean \pm SEM.

\section{NADPH-cytochrome c Reductase}

NADPH-cytochrome $\mathrm{c}$ reductase activity was used as a marker of endoplasmic reticulum in each fraction. Assay buffer $(1 \mathrm{~mL})$ containing $50 \mathrm{mM}$ sodium phosphate, $0.1 \mathrm{mM}$ EDTA, pH 7.7, 50 $\mu \mathrm{L}$ of cytochrome $\mathrm{c}(25 \mathrm{mg} / \mathrm{mL})$ and $50 \mu \mathrm{L}$ of fraction sample were mixed prior to the addition of $100 \mu \mathrm{L}$ of NADPH $(2 \mathrm{mg} /$ $\mathrm{mL}$ ). Absorbance was recorded every $15 \mathrm{~s}$ for $3 \mathrm{~min}$ at $550 \mathrm{~nm}$. The mean specific activity per microgram protein for each fraction was normalized against the specific activity of the total extract (given a value of 1) and data were expressed as mean \pm SEM.

\section{Western Blot Analysis}

This procedure was used for (a) analysis of marker proteins in various subcellular fractions and (b) for validation of protein level changes. Fractions ( $20 \mu \mathrm{g}$ protein) were either pelleted ( $15 \mathrm{~min}$ at $10000 \mathrm{~g}$ ) for mitochondria-enriched fractions or acetone precipitated prior to resuspension in reducing sample buffer (0.125 M Tris, pH 6.8, 20\% [v/v] glycerol, $4 \%[\mathrm{v} / \mathrm{v}]$ SDS, $0.004 \%[\mathrm{w} / \mathrm{v}]$ bromophenol blue, $10 \%[\mathrm{v} / \mathrm{v}] \beta$-mercaptoethanol). Samples were electrophoresed using SDS-PAGE as described by Laemmli ${ }^{53}$ in a $12 \%(\mathrm{w} / \mathrm{v})$ polyacrylamide resolving gel. Proteins separated by SDS-PAGE were transferred onto a nitrocellulose membrane by wet blotting. ${ }^{54}$ Blotting efficiency was checked by staining with copper phthalocyanine $3,4^{\prime}, 4^{\prime \prime}, 4^{\prime \prime \prime}$. tetrasulfonic acid tetrasodium salt in $12.5 \mathrm{mM} \mathrm{HCl}$. Digital images were recorded, blots destained in $12.5 \mathrm{mM} \mathrm{NaOH}$ and membranes blocked by incubation in 3\% (w/v) Marvel milk powder for $1 \mathrm{~h}$ prior to immunoprobing. Blocked membranes were incubated in primary antibody overnight at $4{ }^{\circ} \mathrm{C}$ with gentle shaking. For detection of markers following subcellular fraction, the primary antibodies used were as follows: mouse anti-cytochrome c antibody (1:500 (v/v) dilution; Santa Cruz Biotechnology, Inc.), rabbit anti-GAPDH antibody and rabbit anti-Lamin A/C antibody (1:1000 (v/v); New England Biolabs, U.K.) and rabbit anti-LAMP2 antibody (1:500 (v/v); Abcam plc, U.K.). For validation purposes, the primary antibodies used were as follows: anti-rabbit anti-Hsp60 antibody (1:5000 (v/v) Alexis Biochemicals, U.K), rabbit anti-VDAC antibody (1:1000 (v/v); New England Biolabs, U.K.), goat anti-GOT2 antibody (C-21) $(1: 1000(\mathrm{v} / \mathrm{v})$; Santa Cruz Biotechnology, Inc.), mouse antiHsp70 clone BRM-22 (1:10000 (v/v); Sigma-Aldrich, U.K.), goat anti-fumarase antibody $(1: 1000(\mathrm{v} / \mathrm{v})$; Abnova, Taiwan), mouse anti-ATP synthase $\alpha$-subunit antibody and mouse antiATP synthase subunit d antibody (1:1000 (v/v), Mitosciences, Inc.). Unbound primary antibody was removed by shaking in TBS containing $0.1 \%(\mathrm{v} / \mathrm{v})$ Tween 20 (TBS-tween). Membranes were then incubated for $2 \mathrm{~h}$ at room temperature in either goat anti-mouse, goat anti-rabbit (DAKO Ltd., U.K.) or AffiniPure Bovine Anti-Goat (H+L) (Stratech Scientific, U.K.) immunoglobulins, all bound to horseradish peroxidase (HRP). Blots were finally washed in TBS-tween and incubated with HRP substrates for revelation by enhanced chemilunescence (ECL) following the manufacturer's instructions (Pierce); chemiluminescence was detected using the Fujifilm LAS 3100 (Raytek Scientific 
A

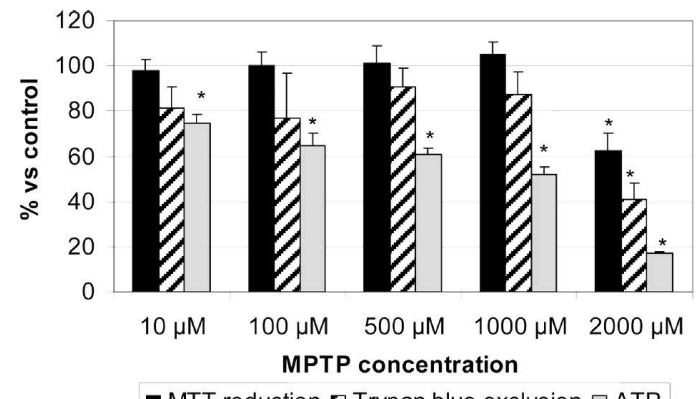

\section{4 hours}

- MTT reduction $\square$ Trypan blue exclusion $\square$ ATP

B

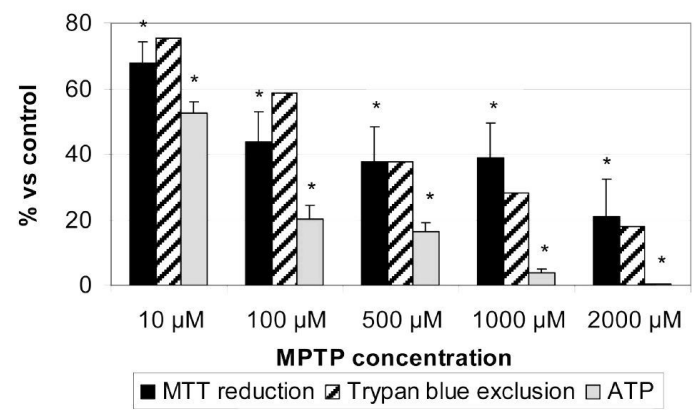

48 hours

C
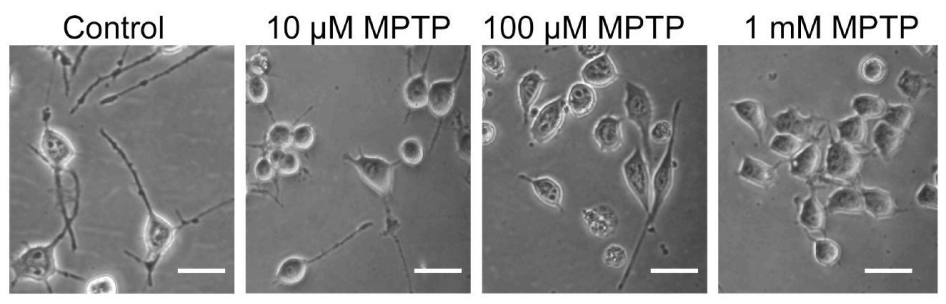

24 hours
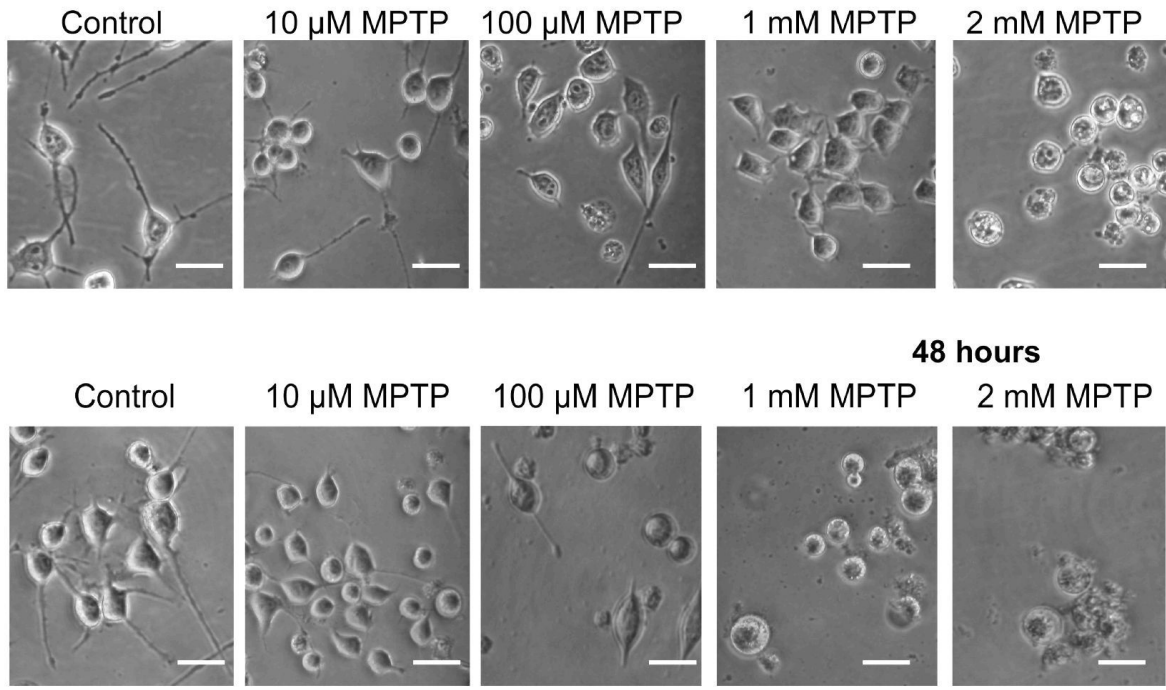

48 hours

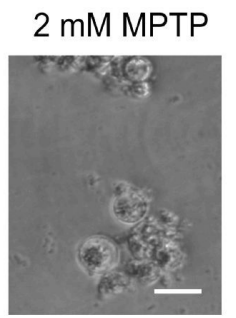

Figure 1. Effects of MPTP on mouse N2a neuroblastoma cell and morphology. Mouse N2a cells were differentiated for $16 \mathrm{~h}$ prior to treatment with different concentrations of MPTP $(0-2 \mathrm{mM}$ ). (A and B) MPTP cytotoxicity was measured using a panel of assays including MTT reduction, trypan blue exclusion and ATP measurement, following (A) $24 \mathrm{~h}$ (MTT, $n=7$; Trypan blue, $n=4$; ATP, $n=6$ ) or (B) $48 \mathrm{~h}$ (MTT, $n=7$; Trypan blue, $n=1$; ATP, $n=$ 3) MPTP treatments $(0-2 \mathrm{mM})$. Results are expressed as mean \% viability \pm SEM. Statistical analysis was carried out using the paired $t$ test with a twotail distribution. ${ }^{*}$ All values $p<0.05$ when compared to respective controls. (C) Digital images taken following 24 or 48 h treatment (using an inverted microscope fitted with phase contrast optics); scale bar represents $20 \mu \mathrm{m}$.

Limited, Germany). Only bands which were nonsaturated were used for analysis. To allow comparison between samples, band intensities were measured using AIDA software according to the manufacturer's instructions (Raytek). Band intensities were first corrected for background and then for protein loading using the corresponding copper stained lane. Each result was then expressed as \% intensity \pm SEM compared to corresponding control.

\section{DE Analysis}

Typically, three gels derived from three mitochondria-enriched preparations were analyzed in each group (treatment versus control). Mitochondria-enriched fractions containing 20 (for comparative analysis) or $80 \mu \mathrm{g}$ of protein (for identification) were pelleted, resuspended in $125 \mu \mathrm{L}$ of sample isoelectrofocusing (IEF) rehydration buffer ( $8 \mathrm{M}$ urea, $4 \%[\mathrm{w} / \mathrm{v}]$ CHAPS, $2 \%$ $[\mathrm{v} / \mathrm{v}]$ carrier ampholyte, $0.0002 \%[\mathrm{w} / \mathrm{v}]$ bromophenol blue, $65 \mathrm{mM}$ DTT) and shaken for $2 \mathrm{~h}$ at room temperature. Samples were applied onto ReadyStrip IPG strips ( $\mathrm{pH} 3-10$, $\mathrm{pH} 5-8$ or $\mathrm{pH} 7-10,7 \mathrm{~cm}$, Bio-Rad, U.K.) and actively rehydrated for $13 \mathrm{~h}$ and $40 \mathrm{~min}$ at $50 \mathrm{~V}$ followed by IEF $(250 \mathrm{~V}$ for $15 \mathrm{~min}$ linear, $4000 \mathrm{~V}$ for $2 \mathrm{~h}$ linear, $4000 \mathrm{~V}$ for $10000 \mathrm{~V} / \mathrm{h}$ rapid) using a PROTEAN IEF cell (Bio-Rad, U.K.). After IEF, strips were 
either stored at $-80^{\circ} \mathrm{C}$ or processed immediately. For equilibration, strips were transferred to $2 \%(\mathrm{w} / \mathrm{v})$ DTT in equilibration buffer ( $6 \mathrm{M}$ urea, $2 \%(\mathrm{w} / \mathrm{v})$ SDS, $20 \%(\mathrm{v} / \mathrm{v})$ glycerol, $50 \mathrm{mM}$ Tris $\mathrm{pH} 8.8$, ) followed by $15 \mathrm{~min}$ in $2.5 \%(\mathrm{w} / \mathrm{v})$ iodoacetamide in equilibration buffer. The proteins were further fractionated by SDS-PAGE (as described above). For comparative purposes, gels were stained using SyproRuby dye following the manufacturer's instructions (Invitrogen, U.K.). Gels were then imaged using a Fujifilm FLA-5100 scanner (Raytek Scientific Limited, Germany) and images were analyzed using Samespots software (Progenesis, U.K.). Data were transferred to the PG240 section of the software. Spots were selected if peak height was over 750 and observed as up- or down-regulated if $p<0.1$ using paired $t$ test carried out by the software and differentially expressed to more than $20 \%$ from one group to another. For identification of protein spots, gels were silver stained (PlusOne Silver staining kit, GE Healthcare) using a mass spectrometry compatible protocol. For $2 \mathrm{D}$-blot analysis, gels were directly processed to wet blotting as described earlier.

\section{Mass Spectrometry Analysis}

Selected spots were excised from the gel, dehydrated in $50 \mu \mathrm{L}$ of acetonitrile (ACN)/25 mM NH $4 \mathrm{HCO}_{3}$ (2:1) for $15 \mathrm{~min}$ while shaking, rehydrated in $50 \mu \mathrm{L}$ of $25 \mathrm{mM} \mathrm{NH}_{4} \mathrm{HCO}_{3}$ for 10 min, and then sequentially dehydrated, rehydrated, and dehydrated. Gel pieces were then dried and $15 \mu \mathrm{L}$ of $12.5 \mathrm{ng} / \mu \mathrm{L}$ sequencing grade trypsin (Promega, U.K.) was added. Gel spots were incubated at $37{ }^{\circ} \mathrm{C}$ for $4 \mathrm{~h}$. Tryptic digests were then transferred to fresh tubes and $10 \mu \mathrm{L}$ of $4: 1 \mathrm{ACN} / \mathrm{LC}-\mathrm{MS}$ grade water $(\mathrm{v} / \mathrm{v})$ was added to the gel pieces and left for $15 \mathrm{~min}$ while shaking. The supernatant was combined with the previous digest and $5 \mu \mathrm{L}$ of $0.1 \%$ trifluoroacetic acid (TFA) was added to each tube. Finally, $1 \mu \mathrm{L}$ sample was plated on the MALDI plate followed by $1 \mu \mathrm{L}$ of $10 \mathrm{mg} \alpha$-cyano-4-hydroxycinnamic acid (CHCA) matrix (LaserBio Laboratories, France) $/ \mathrm{mL}$ in $50 \%(\mathrm{v} / \mathrm{v}$ ) $\mathrm{ACN} / 0.1 \%(\mathrm{v} / \mathrm{v})$ TFA. Peptide mass fingerprints were generated using a MALDI-TOF mass spectrometer (Axima mass spectrometer, Shimadzu, U.K.). Proteins were identified using the Mascot search engine (http://www.matrixscience.com); stating "mus musculus" species, carboxymethyl and oxidized methionine as variable modifications and 0.2 Da peptide tolerance. Positive identity was given by scores over 56 (comparing Swiss-Prot database) and their molecular mass and $\mathrm{p} I$ were compared to the position of the spot on the $2 \mathrm{DE}$.

\section{Statistical Analysis}

Data were statistically analyzed by a paired $t$ test using a twotailed distribution.

\section{RESULTS}

\section{MPTP Cytotoxicity in Differentiated Mouse N2a Neuroblas- toma Cells}

Following $16 \mathrm{~h}$ differentiation, N2a cells were treated with different concentrations of MPTP for either 24 or $48 \mathrm{~h}$. Cytotoxic effects of MPTP were determined using a range of assays (Figure 1). Following $24 \mathrm{~h}$ exposure to MPTP, ATP levels dropped in a concentration dependent-manner; $10 \mu \mathrm{M}$ MPTP significantly decreased ATP levels by $25 \%$ and $2 \mathrm{mM}$ MPTP reduced ATP by more than $80 \%$ (Figure $1 \mathrm{~A}$ ). Both trypan blue exclusion and MTT reduction assays showed that cell viability was significantly reduced following $24 \mathrm{~h}$ exposure to $2 \mathrm{mM}$ MPTP but not at lower MPTP concentrations (Figure 1A).
$\mathbf{A}$

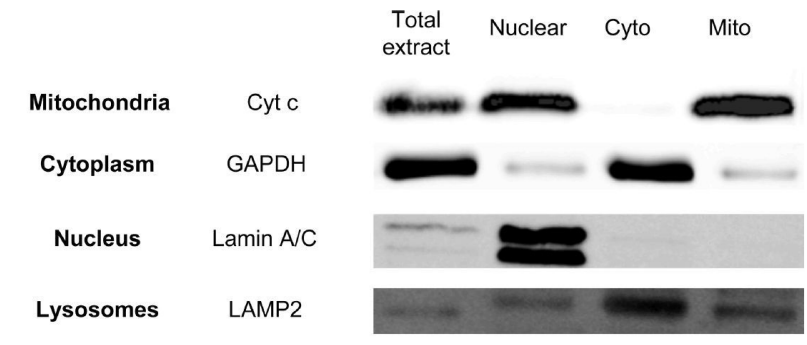

B

\begin{tabular}{|c|c|c|c|}
\hline \multicolumn{2}{|c|}{ Markers } & \multicolumn{2}{|r|}{ Fractions } \\
\hline Location & Protein & Nucleus & cytoplasm mitochondria \\
\hline \multirow{2}{*}{ Mitochondria } & $\mathrm{SDH}^{1}$ & $2.38 \pm 0.20^{*}$ & $0.00 \pm 0.00^{*} \quad 4.5 \pm 1.24^{*}$ \\
\hline & Cyt c ${ }^{2}$ & $1.91 \pm 0.95$ & $0.52 \pm 0.13^{*} 13.34 \pm 4.59^{*}$ \\
\hline \multirow{2}{*}{ Cytoplasm } & $\mathrm{LDH}^{1}$ & $0.92 \pm 0.60$ & $0.79 \pm 0.53 \quad 0.12 \pm 0.06$ \\
\hline & $\mathrm{GAPDH}^{2}$ & $0.25 \pm 0.20^{*}$ & $0.9 \pm 0.33 \quad 0.15 \pm 0.06^{*}$ \\
\hline Nucleus & Lamin $^{2}$ & $\begin{array}{l}27.51 \pm \\
10.18^{*}\end{array}$ & $0.69 \pm 0.38 \quad 0.39 \pm 0.08^{*}$ \\
\hline Lysosome & LAMP2 $^{2}$ & $0.45 \pm 0.20$ & $4.44 \pm 2.30^{*} \quad 2.31 \pm 2.24$ \\
\hline $\begin{array}{c}\text { Endoplasmic } \\
\text { reticulum }\end{array}$ & $\begin{array}{l}\mathrm{NADPH}-\mathrm{cyt} \\
\mathrm{c}^{\text {reductase }}\end{array}$ & $0.48 \pm 0.20$ & $1.12 \pm 0.08 \quad 0.25 \pm 0.12^{*}$ \\
\hline
\end{tabular}

Figure 2. Assessment of purity of various subcellular fractions using marker proteins. Mouse N2a cells were differentiated for $16 \mathrm{~h}$ prior to homogenization followed by differential centrifugation. The presence of a variety of markers was analyzed by Western blotting and enzyme activity assays. (A) Representative Western blots ( $20 \mu \mathrm{g}$ loading in each well) showing the presence of a series of markers in each fraction (total extract, nuclear, cytoplasmic, mitochondrial). (B) Table of quantified results from activity assays ${ }^{1}$ and Western blots using Aida software ${ }^{2}{ }^{1}$ Specific activity of each enzyme measured was calculated relative to total extract (given a value of 1 ) $\pm \operatorname{SEM}(n \geq 4)$. ${ }^{*}$ All values $p<0.05$ when compared to total extract using a paired $t$ test with a two-tail distribution. ${ }^{2}$ Intensity of bands in each fraction was measured and quantified relative to total extracts (given a value of 1$) \pm \operatorname{SEM}(n \geq 13)$. Cyt $c$, cytochrome c; Cyto, cytoplasmic; ER, endoplasmic reticulum; GAPDH, glyceraldehyde 3-phosphate dehydrogenase; LAMP2, lysosomal-associated membrane protein 2; LDH, lactate dehydrogenase; Mito, mitochondrial; NADPH-cyt $\mathrm{c}$ reductase, nicotinamide adenine dinucleotide phosphate-cytochrome $\mathrm{c}$ reductase; $\mathrm{SDH}$, succinate dehydrogenase.

By $48 \mathrm{~h}, 10 \mu \mathrm{M}$ MPTP reduced cell viability as measured by MTT and trypan blue (Figure $1 \mathrm{~B}$ ). Following $24 \mathrm{~h}$ treatment, cell morphology indicated that cell death occurred at a concentration of $2 \mathrm{mM}$ MPTP, represented by a reduction in cell volume, a spherical cell shape and a loss of membrane integrity (Figure 1C). Nevertheless, shortening of axon-like processes was apparent with MPTP concentrations as low as $10 \mu \mathrm{M}$ MPTP, exacerbated as MPTP concentration was increased. Following $48 \mathrm{~h}$ exposure, 10 $\mu \mathrm{M}$ MPTP resulted in a few rounded dead cells; however, cell death was more evident with $100 \mu \mathrm{M}$ and higher concentrations of MPTP.

To conclude, cell morphology and ATP levels were affected at lower MPTP concentrations than apparent cell death measured using trypan blue exclusion and MTT reduction. A concentration affecting morphology/ATP but not MTT reduction/trypan blue exclusion was defined as subcytotoxic and was chosen to observe changes occurring in the mitochondrial proteome prior to cell death. Consequently further analyses were carried out using $1 \mathrm{mM}$ MPTP for $24 \mathrm{~h}$.

\section{Purity of Mitochondria-Enriched Fractions}

The mitochondrial markers cytochrome $c$ and SDH were highly enriched (4.5- and 13-fold, respectively) in the mitochondrial pellet, while present at low levels in the nuclear pellet and 

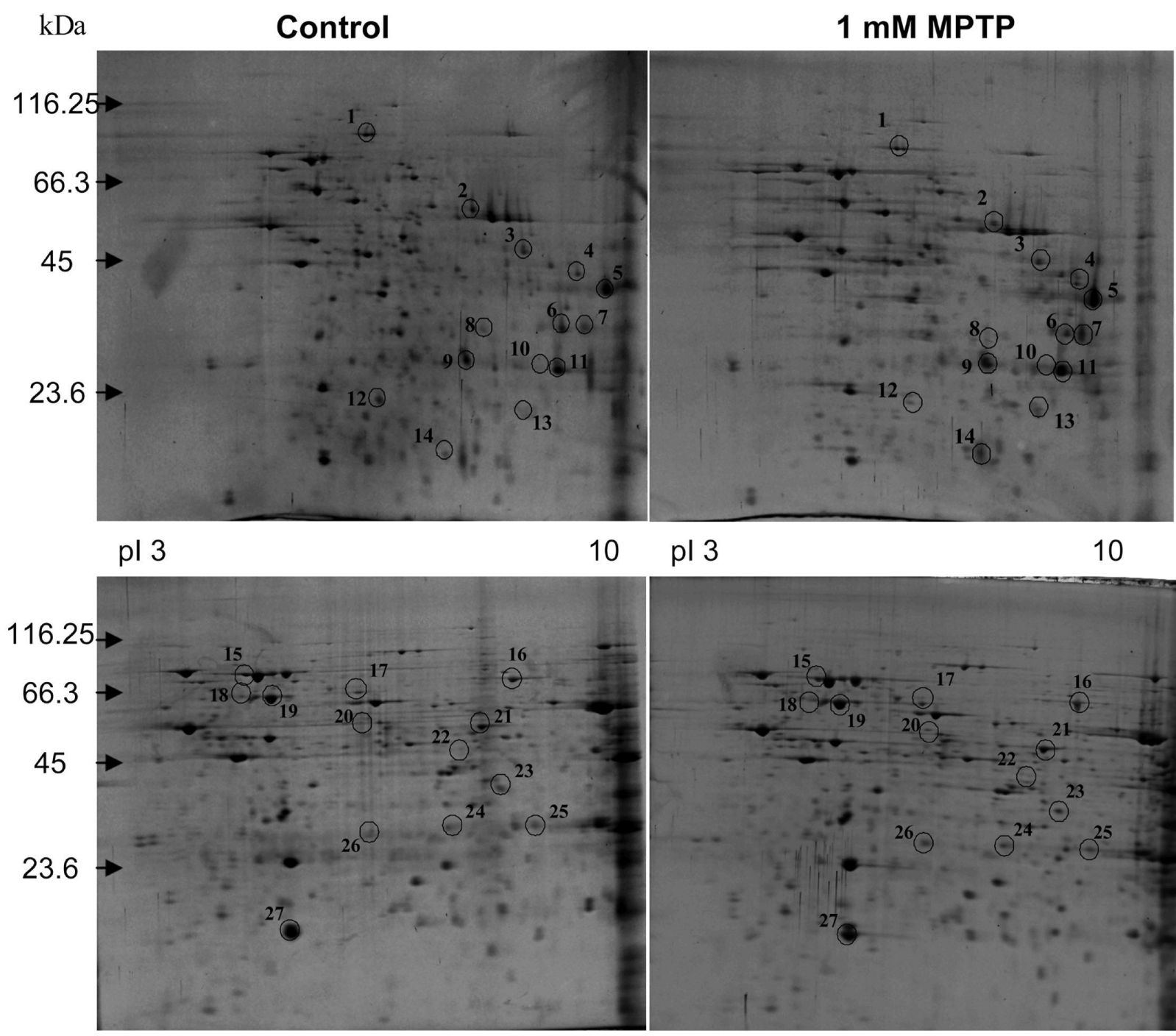

pl 5

8

pl 3

10

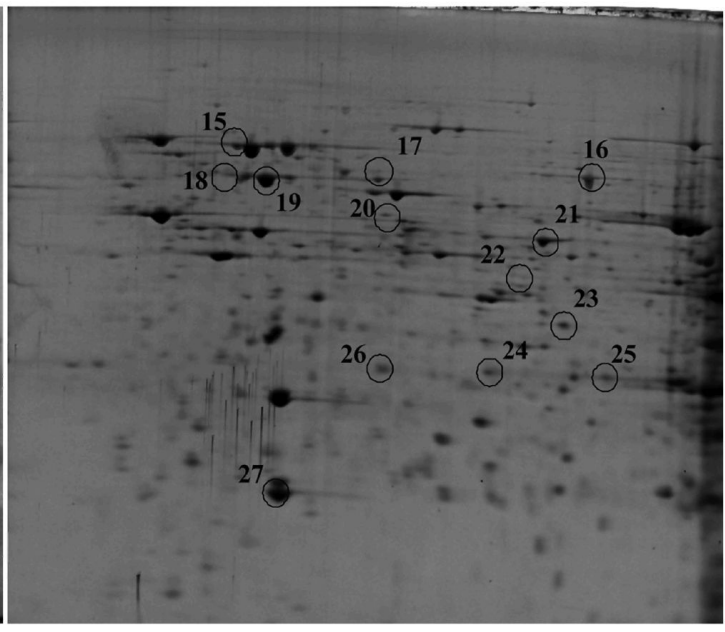

pl 5

8

Figure 3. Effects of subcytotoxic concentrations of MPTP on the N2a mitochondrial proteome. Mouse N2a cells were differentiated for $16 \mathrm{~h}$ prior to treatment with $1 \mathrm{mM}$ MPTP for $24 \mathrm{~h}$. Mitochondrial pellets were isolated and fractionated $(50 \mu \mathrm{g})$ by $2 \mathrm{DE}$ using pH $3-10$ and $\mathrm{pH} 5-8$ gradient strips, and proteins visualized using SyproRuby. Gel images were compared using Samespots software. Circled spots represent spots that changed in density ( $p$ $<0.1$ ) between $1 \mathrm{mM}$ MPTP and control samples following a student paired $t$ test. A list of identified proteins affected by MPTP treatment is provided in Table 1 .

highly depleted in the cytoplasmic fraction (Figure 2). Cytoplasmic, nuclear and endoplasmic reticulum (ER) markers were minimal within the mitochondria-enriched fraction; however, the lysosomal marker LAMP2 appeared to be enriched in the mitochondrial fraction compared to the total extract but this was not stastistically significant. The majority of the lysosomal marker was present in the cytoplasmic fraction (enriched 4.4fold compared to total extract; Figure 2). Overall, subcellular marker analysis showed that the mitochondrial fraction was composed mainly of mitochondrial proteins and contained a low level of the lysosomal protein marker. The cytoplasmic fraction also contained low levels of noncytoplasmic protein markers. Thus, both mitochondrial and cytoplasmic fractions were deemed to be suitable for further analyses. On the other hand, the nuclear fraction contained significant levels of cytoplasmic and mitochondrial markers (Figure 2), probably indicative of incomplete cellular disruption (at least $25 \%$ nonlysed cells as measured by microscopic analysis, data not shown), and was therefore not used for further analysis. The relative distribution of a particular marker was not affected by MPTP treatment (refer to Supplementary Data 4).

\section{Effects of Subcytotoxic MPTP Treatments on the Mitochon-} drial Proteome

Mitochondrial fractions from cells treated with $1 \mathrm{mM}$ MPTP for $24 \mathrm{~h}$ were analyzed using $2 \mathrm{DE}$. Figure 3 shows $2 \mathrm{DE}$ profiles for treated and control samples using either broad ( $\mathrm{pH} 3-10$ linear) or narrower $(\mathrm{pH} 5-8) \mathrm{pH}$ gradient strips. Using the broad range strips, approximately 350 spots were detected. Up to 6 proteins showed changes in levels following MPTP treatment with $p<0.05$ using the software's in-built paired $t$ test. To ensure detection of as many differentially expressed proteins as possible, spots showing a change with a probability $p<0.1(n=3)$, discriminated from spots with $p<0.05$, were also selected for 
Table 1. List of Identified Proteins Significantly Altered by MPTP Treatment ${ }^{a}$

\begin{tabular}{|c|c|c|c|c|c|c|c|c|c|c|}
\hline spot no. & controls ${ }^{c}$ & treatments ${ }^{c}$ & $\%$ change & protein identification & accession no. & score $^{e}$ & coverage $^{f}$ & $\mathrm{kDa}$ & $\mathrm{p} I$ & localization \\
\hline \multicolumn{11}{|c|}{ Chaperone Family } \\
\hline 12 & $521 \pm 41$ & $337 \pm 417$ & $-35 \%{ }^{*}$ & ERP29 & P57759 & 185 & $49 \%$ & 29 & 5.90 & ER \\
\hline 15 & $454 \pm 61$ & $761 \pm 91$ & $+68 \%^{+}$ & $\mathrm{Hsc} 70$ & P63017 & 83 & $27 \%$ & 71 & 5.37 & Ubiquitous \\
\hline 16 & $1564 \pm 386$ & $2095 \pm 376$ & $+34 \%^{+}$ & STIP1 & Q60864 & 79 & $20 \%$ & 63 & 6.40 & Ubiquitous \\
\hline 17 & $302 \pm 44$ & $389 \pm 37$ & $+29 \% *$ & TCPE & P80316 & 90 & $22 \%$ & 60 & 5.72 & Ubiquitous \\
\hline 19 & $3040 \pm 150$ & $3863 \pm 161$ & $+27 \%^{+}$ & Hsp60 & P63038 & 113 & $27 \%$ & 61 & 5.91 & Matrix \\
\hline \multicolumn{11}{|c|}{ Metabolic Enzymes } \\
\hline 2 & $1428 \pm 148$ & $1709 \pm 136$ & $+20 \%^{+}$ & SCOT1 & Q9DOK2 & 62 & $14 \%$ & 56 & 8.73 & Matrix \\
\hline 3 & $1123 \pm 70$ & $1438 \pm 129$ & $+28 \%{ }^{+}$ & FMH & P97807 & 103 & $43 \%$ & 54 & 9.12 & IMM \\
\hline 5 & $5559 \pm 916$ & $6900 \pm 628$ & $+24 \%^{*}$ & GOT2 & P05202 & 89 & $22 \%$ & 41 & 9.00 & Matrix \\
\hline 6 & $1077 \pm 249$ & $1589 \pm 179$ & $+48 \%$ & $\mathrm{MDH}$ & P08249 & 177 & $44 \%$ & 36 & 8.93 & Matrix \\
\hline 7 & $2416 \pm 211$ & $3758 \pm 70$ & $+56 \% *$ & $\mathrm{MDH}$ & P08249 & 101 & $43 \%$ & 36 & 8.93 & Matrix \\
\hline 13 & $386 \pm 77$ & $829 \pm 135$ & $+115 \% *$ & ECHM & Q8BH95 & 83 & $48 \%$ & 31 & 8.76 & Matrix \\
\hline 21 & $1122 \pm 103$ & $1648 \pm 104$ & $+47 \%^{+}$ & ENOA & P17182 & 335 & $75 \%$ & 47 & 6.37 & Cyto-mb \\
\hline \multicolumn{11}{|c|}{ Oxidative Phosphorylation } \\
\hline 9 & $802 \pm 27$ & $1194 \pm 38$ & $+49 \% *$ & ETF $\alpha$ & Q99LC5 & 65 & $17 \%$ & 35 & 8.62 & Matrix \\
\hline 27 & $3872 \pm 447$ & $5530 \pm 614$ & $+43 \% *$ & ATPase-d & $\mathrm{Q9DCX} 2$ & 150 & $85 \%$ & 19 & 5.88 & IMM \\
\hline \multicolumn{11}{|c|}{ Mitochondrial Membrane Proteins } \\
\hline 1 & $584 \pm 67$ & $438 \pm 24$ & $-25 \%^{+}$ & IMMT & Q8CAQ8 & 210 & $34 \%$ & 84 & 6.18 & IMM \\
\hline 11 & $3954 \pm 454$ & $5123 \pm 766$ & $+30 \%{ }^{+}$ & VDAC1 & Q60932 & 196 & $81 \%$ & 30 & 8.62 & $\mathrm{OMM}$ \\
\hline
\end{tabular}

${ }^{*}$ Statistically significant changes $p<0.05$ using a paired $t$ test. ${ }^{\dagger}$ Statistically significant changes $p<0.1$ using a paired $t$ test. ATP synthase- $\alpha$, ATP synthase $\alpha$-subunit isoform 1; ATP synthase-d, ATP synthase subunit-d; Cyto-mb, membrane protein on cytoplasmic side; ECHM, EnoylCoA hydratase mitochondrial; ENOA, $\alpha$-enolase; ERp29, endoplasmic reticulum resident protein 29; ETF $\alpha$, electron transfer flavoprotein subunit- $\alpha$; FMH: fumarase; GOT2, glutamate oxaloacetate transaminase 2; Hsp60:,60 kDa heat shock protein; Hsc70, heat shock cognate $71 \mathrm{kDa}$; IMM, inner mitochondrial membrane; Matrix, mitochondrial matrix; MDH, malate dehydrogenase; OMM, outer mitochondrial membrane; SCOT1, succinylCoA:3-ketoacid-coenzyme A transferase 1, STIP1, stress-induced protein 1; TCPE, T-complex protein 1 subunit epsilon; VDAC1, Voltage-dependentanion channel $1 .{ }^{b}$ Spot numbers can be mapped back to show their positions in Figure $3 .{ }^{c}$ Average of normalized volumes $(n=3) \pm S E M$. ${ }^{d}$ Accession number from the Protein Knowledgebase UniProtKb: http://www.uniprot.org. ${ }^{e}$ Protein score greater than 54 are significant according to the Mascot database. ${ }^{f}$ Coverage of all peptide sequences matched to the identified protein sequence.

identification and for validation analysis, leading to the identification of at least 14 differentially expressed proteins following treatment. Most of these changes were in the basic area of the gel. Enriching the neutral $\mathrm{pH}$ area $(\mathrm{pH} 5-8)$ showed that more proteins were affected (13 spots) by the toxin treatment than observed using the broad $\mathrm{pH}$ gradient strips in the same area. Combining both analyses, 27 spots were either up- or downregulated following exposure to MPTP of which 16 were identified. Table 1 shows the list of identified proteins affected by subcytotoxic concentrations of MPTP, including proteins from the chaperone family, metabolic enzymes, subunits of oxidative phosphorylation and membrane proteins. Most of these proteins are either known to have distinct localizations in mitochondria, or to be ubiquitously distributed within a cell.

\section{Validation of Potential Markers of MPTP Subcytotoxicity}

To confirm the changes observed, some of these proteins were further analyzed by probing Western blots with specific antibodies. In addition to mitochondria-enriched fractions, the levels of these proteins were measured in unfractionated ('total') extracts and cytoplasmic fractions. The Western blotting data (top of each panel, Figure 4) shows that, except for Hsc70 (localized ubiquitously in the cell), proteins were found in lower levels in the cytoplasmic fraction, in line with specific localization to mitochondria. More particularly, VDAC1 and ATP synthase-d were not detected in the cytoplasmic fraction (Western blot images shown in Figure 4B,C). Western blot analysis indicated that all proteins whose levels in the mitochondrial proteome changed following MPTP treatment showed the same trend using Western blot analysis. Specifically, FMH, VDAC1, ATP synthase-d, GOT2, Hsp60 and Hsc70 were all significantly upregulated in mitochondria following treatment, validating the results from the $2 \mathrm{DE}$ analysis (Figure 4 and Table 2 ).

In general, the percentage changes were higher using the Western blot analysis than the 2DE approach. Western blot analysis of the mitochondrial protein ATP synthase $\alpha$-subunit, chosen as a control since $2 \mathrm{DE}$ indicated that its level did not significantly change following MPTP treatment, also revealed no change in its level (Table 2).

Hsc70 levels increased in the mitochondria-enriched fraction but this increase was not detectable in total extracts due to the fact that there was no increase in the cytoplasmic fraction, where it was most prevalent (Figure 4D).

Two-dimensional gel electrophoresis technology can separate isoforms of the same protein, whereas $1 \mathrm{D}$-Western blot analysis provides a measure of total protein levels within a single band. Therefore, further analysis focusing on isoforms of the same protein was carried out for the heat shock proteins and VDAC1 using 2D-Western blot analysis. Figure 5A (left panel) shows that two Hsc70 isoforms were detected using Western blotting. The main spot (spot 15') was identified as Hsc70 (refer to Supplementary Data 1 and Figure $5 \mathrm{~A}$ right panel) whose levels were not 

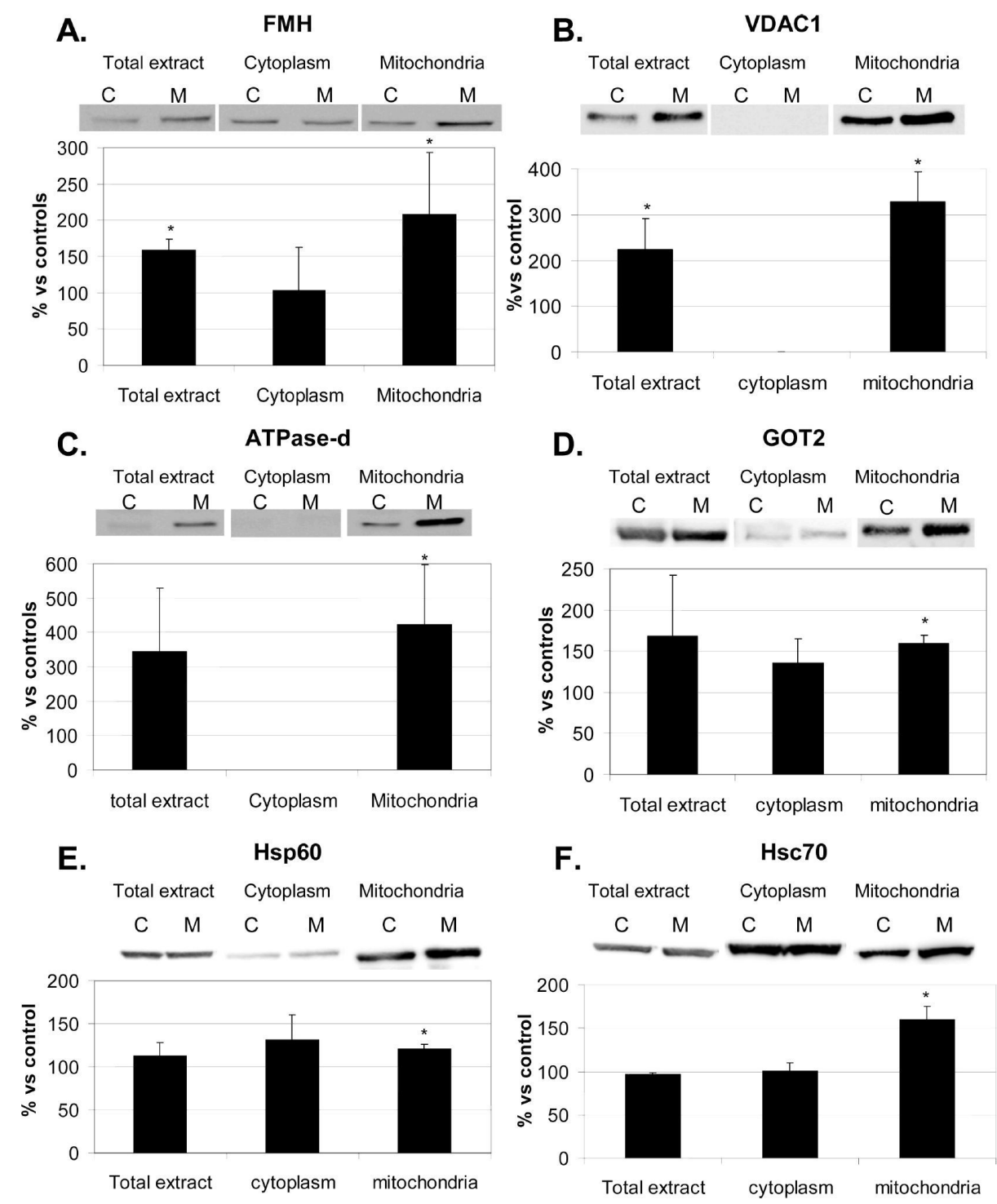

Figure 4. Validation and quantification of identified changes in cellular fractions from mouse N2a neuroblastoma following treatment with subcytotoxic concentrations of MPTP. Mouse N2a cells were differentiated for $16 \mathrm{~h}$ prior to treatment with $1 \mathrm{mM}$ MPTP and subcellular fractionation peformed. Western blotting analysis was performed on different fractions (total extract, cytoplasmic and mitochondrial). Blots were detected for the presence of (A) fumarase, (B) VDAC1, (C) ATP synthase d subunit, (D) GOT2, (E) Hsp60, and (F) Hsc70. Densitometry of Western blots was quantified using Aida software, each band compared to total protein $(20 \mu \mathrm{g}$ equal loading/well). Data represented as \% protein marker/total protein compared to controls $(n \geq 4)$. Statistically significant changes $p<0.05$ using a paired $t$ test. ATP synthase-d, ATP synthase subunit $\mathrm{d}$; FMH, fumarase; C, control sample; GOT2, glutamate oxaloacetate transaminase 2; Hsp60, $60 \mathrm{kDa}$ heat shock protein; Hsc70, heat shock cognate 71 kDa; M, MPTP-treated sample; VDAC1, voltage-dependent-anion channel 1.

found to be affected by MPTP treatment (Figure 3). In contrast, the smaller acidic spot (spot 15, Figure 5A) became more prominent following treatment with MPTP (Figure 3).

Up to three Hsp60 isoforms were detected by Western blotting: the predominant spot, colocalizing with spot 19 from Figure 3 (also right panel Figure 5B), plus two smaller spots of same molecular weight (Figure 5B, left panel). Only the main central spot increased in levels following MPTP treatment.

$2 \mathrm{D}$-blot analysis revealed a number of VDAC1 spots; the main spot (spot 11) was associated with three small relatively acidic spots and a number of isoforms (represented as a smear) with a more alkaline isoelectric point (Figure 5C, left panel). The main spot stained more intensely on 2D-blots of MPTP-treated cell extracts.

\section{DISCUSSION}

Effects of Subcytotoxic Concentrations of MPTP on the Mitochondrial Proteome from Mouse N2a Neuroblastoma

In the present study, treatment with up to $1 \mathrm{mM}$ MPTP for 24 $\mathrm{h}$ was considered subcytotoxic in differentiated mouse N2a cells; cell viability assessed using trypan blue exclusion and MTT reduction was not affected but morphological changes and reduced ATP levels were observed. Interestingly, even though ATP levels were reduced following treatment with low MPTP concentrations (as low as $10 \mu \mathrm{M}$ ), cell death only significantly occurred when more than $50 \%$ ATP was depleted suggesting that a threshold ATP level (20-50\% of controls in the present model, Figure 1A) might be required for maintaining the survival of the 
Table 2. Comparison of Western Blot Data (1D-blot) with 2DE Analysis ${ }^{a}$

$\begin{array}{lcr}\text { protein identification } & 2 \mathrm{DE} & 1 \mathrm{D} \text {-blot } \\ \text { FMH } & +28 \%^{\dagger} & +108 \%^{*} \\ \text { VDAC1 } & +30 \%^{\dagger} & +228 \%^{*} \\ \text { ATP synthase-d } & +43 \%^{\dagger} & +324 \%^{*} \\ \text { GOT2 } & +24 \%^{*} & +59 \%^{*} \\ \text { Hsp60 } & +27 \%^{\dagger} & +20 \%^{*} \\ \text { Hsc70 } & +68 \%^{\dagger} & +60 \%^{*} \\ \text { ATP synthase- } \alpha & +17 \%^{+} & +11 \%\end{array}$

${ }^{a}$ Densitometry of Western blots shown in Figure 4 was compared to $2 \mathrm{DE}$ analysis (data presented in Figure 3 ). ATP synthase- $\alpha$ was used as a control protein, exhibiting no changes in levels. *Statistically significant changes $p<0.05$ using a paired $t$ test. ${ }^{+}$Statistically significant changes $p<$ 0.1 using a paired $t$ test. ATP synthase- $\alpha$, ATP synthase $\alpha$-subunit isoform 1; ATPsynthase-d, ATP synthase subunit d; FMH, fumarase; GOT2, glutamate oxaloacetate transaminase 2; HSP60, $60 \mathrm{kDa}$ heat shock protein; HSPA8, heat shock cognate $71 \mathrm{kDa}$; VDACI, voltagedependent-anion channel 1.
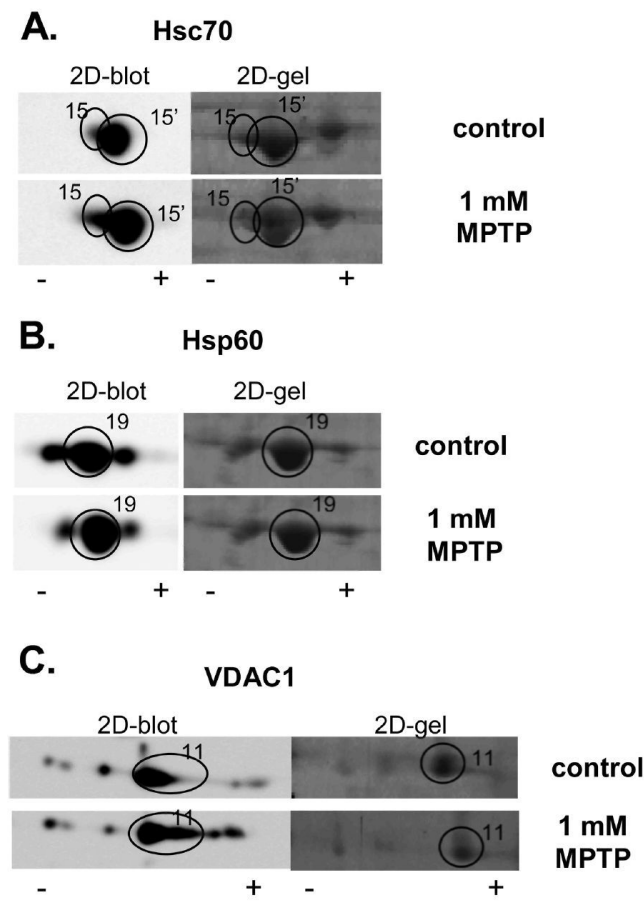

Figure 5. Isoform detection of heat shock proteins and VDAC1 shown to be differentially expressed following MPTP treatment using 2D-blot. Mouse N2a cells were differentiated for $16 \mathrm{~h}$ prior to treatment with $1 \mathrm{mM}$ MPTP. Mitochondrial pellets were isolated and fractionated (50 $\mu \mathrm{g})$ by $2 \mathrm{DE}$ followed by transfer to nitrocellulose membranes and detected for Hsc70 (A), Hsp60 (B), and VDAC1 (C) presence. Each $2 \mathrm{D}$-blot (representative experiment) is accompanied by the corresponding area of $2 \mathrm{DE}$ from Figure 3. All circled spots were identified by peptide fingerprinting. Numbered spots correspond to those in Figure 3. Spots 15 and A, Hsc70; Spot 19, Hsp60; Spot 11, VDAC1. -, acidic end; + , basic end.

cells. In the present model, reduced ATP levels were probably a direct consequence of complex I inhibition. ${ }^{55,56}$ The subcytotoxic effects on neuronal morphology could be due to altered cytoskeletal protein arrangement as previously noted. Indeed, De Girolamo and colleagues ${ }^{42}$ showed that a reduction in axonal outgrowth was linked to hyperphosphorylation of neurofilaments NF-H, leading to a change in the stability of the cytoskeleton. Similarly to the present study, this phenomenon occurred prior to cell death. ${ }^{42}$

To focus on mitochondrial dysfunction, mitochondria were enriched from differentiated mouse N2a cells. The use of markers for each subcellular fraction showed that the resulting mitochondrial preparation was highly enriched in mitochondrial proteins, contained low levels of lysosomal proteins and traces of cytoplasmic and endoplasmic reticulum proteins (Figure 2). Only $10 \%$ of the identified proteins from the mitochondrial proteome 2DE profile were not specific to mitochondria (refer to Supplementary Data 2 for localization of each identified protein), including proteins normally found in the cytosol and endoplasmic reticulum, confirming the subcellular marker data. The purity of the mitochondria-enriched fraction and $2 \mathrm{DE}$ profile was comparable with the study of Scheffler and colleagues ${ }^{57}$ (3.7fold mitochondrial enrichment, low contamination levels) and better than that observed in the study of Pennington and colleagues. $^{33}$

Proteomic analysis using the $2 \mathrm{DE}$ approach showed that the levels of 27 proteins changed following MPTP treatment and 16 of these proteins were identified. Because of a relatively low statistical power ( $p<0.1$ using paired $t$ test; $n=3$ ), validation of the approach was essential. The availability of well characterized commercial antibodies allowed further analysis of expression levels of six proteins using Western blot analysis; changes in expression of these proteins were confirmed, validating the $2 \mathrm{DE}$ data.

The differentially expressed proteins were from different cellular pathways. Dysregulation in protein folding was indicated by increased levels of some chaperone family proteins, such as the ubiquitous heat shock cognate $71 \mathrm{kDa}$ (Hsc70) and stressinduced protein 1 (STIP1), the cytoplasmic T-complex protein-1 $\varepsilon$-subunit (TCPE) and the mitochondrial $60 \mathrm{kDa}$ heat shock protein (Hsp60), and with decreased levels of endoplasmic reticulum resident protein 29 (ERP29) in the mitochondrial fraction. The levels of proteins involved in several metabolic pathways were increased following MPTP-treatment, including: MDH and FMH (Krebs cycle), GOT2 (amino acid metabolism), ECHM and ETF $\alpha$ (fatty acid $\beta$-oxidation), SCOT1 (ketone body metabolism), enolase (glycolysis) and ATP synthase-d (oxidative phosphorylation). Two membrane proteins were also affected with increased levels of VDAC1 and decreased levels of mitofilin. The present study showed that many mitochondrial pathways could be affected by MPTP treatment prior to cell death.

\section{Changes in Metabolic Pathways}

While ATP levels were reduced by $50 \%$ following MPTP treatment, ATP synthase subunit d levels (ATP synthase-d) increased, whereas ATP synthase F1 complex $\alpha$-subunit (ATP synthase- $\alpha$ ) levels were unaffected. These different effects on the two subunits within complex $\mathrm{V}$ were not unexpected given that the subunits have different functions, with the $\alpha$-subunit binding nucleotides and subunit-d participating in stabilizing the F1/F0 complex. ${ }^{58}$ Increased subunit-d could be a compensatory mechanism in response to declining ATP levels. Indeed, these results agree with the observations of Basso and colleagues ${ }^{59}$ in human post-mortem samples of the substantia nigra, and thereby support the use of the N2a model for this type of analysis.

As indicated earlier, the protein levels of several metabolic enzymes were up-regulated following treatment with subcytotoxic concentrations of MPTP. The role of the proteins in the various 


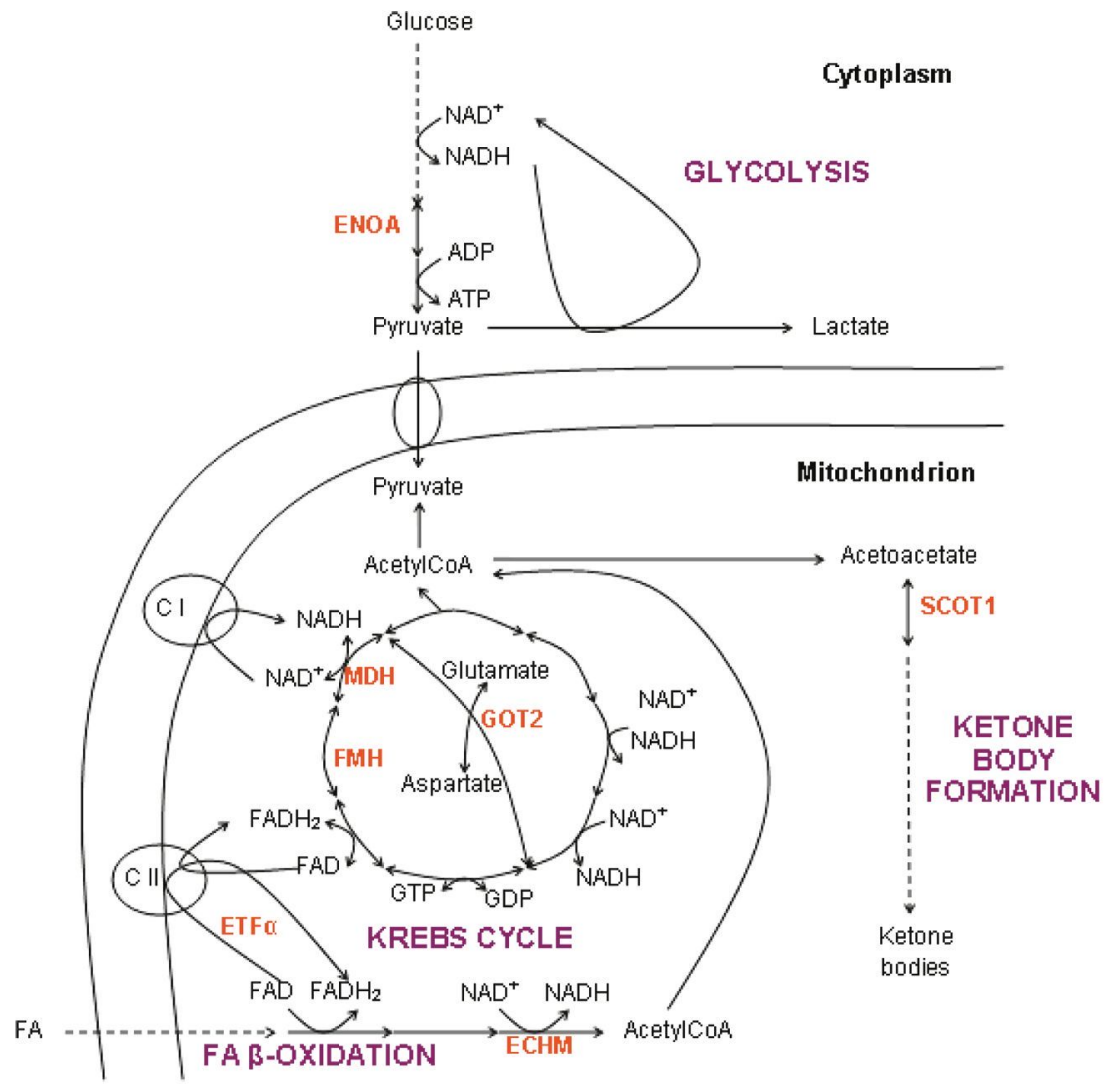

Figure 6. Simplified schematic presentation of metabolic pathways involved in MPTP-induced toxicity. Enzyme proteins in orange bold were observe to increase following MPTP treatment in the present study (refer to Figure 3). Metabolic pathways are indicated in purple. ECHM, enoylCoA hydratase mitochondrial; ENOA, $\alpha$-enolase; ETF $\alpha$, electron transfer flavoprotein subunit- $\alpha$; FMH, fumarase; GOT2, glutamate oxaloacetate transaminase 2; MDH, malate dehydrogenase; SCOT1, succinyl-CoA:3-ketoacid-coenzyme A transferase.

pathways and possible interactions between the proteins are summarized in Figure 6. An increase in enolase suggests an activation of the glycolytic pathway, thought to be protective in MPTP-induced toxicity models via the production of more ATP. ${ }^{60,61}$ Fatty acid oxidation may also be increased in our model, suggested by increased levels of ETF $\alpha$ and ECHM, again leading to more ATP production.

One consequence of complex I inhibition is the inability to reoxidize $\mathrm{NADH}$ via the electron transfer chain. ${ }^{18}$ It has been proposed that the reversal of the $\mathrm{MDH}$ step to produce malate may protect mouse N2a cells against MPTP toxicity, also allowing NADH reoxidation. ${ }^{62}$ Therefore, it is possible that the increased levels of $\mathrm{MDH}$ reported in the present study reflect an attempt to reoxidize $\mathrm{NADH}$. Evidence of $\mathrm{FMH}$ involvement has not been observed in other PD studies but one can speculate that increased FMH levels may similarly serve the purpose of increasing the production of malate as a substrate for cytosolic energy production (Figure 6). The consequence of increased levels of GOT2 is not known in the present model but it should be noted that a previous study of the effects of MPTP on monkeys showed that MDH and GOT2 activities were increased. ${ }^{63}$ Glutamate oxaloacetate transaminase 2 (GOT2), also called mitochondrial aspartate aminotransferase, is linked to the Krebs cycle (Figure 6) in the mitochondrial matrix ${ }^{64}$ Increased extracellular glutamate levels have previously been described in $\mathrm{PD}^{65}$ and following MPTP-induced toxicity. ${ }^{66} \mathrm{~A}$ role for glutamate excitotoxicity in cell death following MPTPinduced toxicity has been observed in a mouse model ${ }^{66}$ and GOT2 increased levels might be involved in the process linking metabolic dysregulation and glutamate excitotoxicity.
A consequence of an inability to oxidize acetylCoA may also be evident since the levels of SCOT1, involved in ketone body formation, are increased. Ketone body formation has previously been described as a protective mechanism of cells in PD models. ${ }^{67,68}$ However, changes in levels of SCOT1 have not previously been reported in relation to complex I inhibition.

\section{Chaperone Family Proteins}

The levels of four chaperones within the mitochondria were increased in response to MPTP treatment. This type of response has commonly been reported under oxidative stress, often linked to protein aggregation and degradation impairment, ${ }^{69}$ as observed in PD models and MPTP-induced models. ${ }^{8,11,70}$ Increased levels of $\mathrm{Hsc} 70$, an ubiquitous protein, were only evident in the mitochondria-enriched fraction where an acidic isoform of the protein was specifically affected. Changes in posttranslational modifications to $\mathrm{Hsc} 70$ have been previously observed in a number of models including nitration, ${ }^{71}$ oxidation ${ }^{72}$ and phosphorylation. ${ }^{73}$ The exact cause of the shift in $\mathrm{pI}$ in the present study and the consequence on mitochondrial location and chaperone function require further study. Hsc70 is involved in folding proteins as they exit ribosomes and in delivering proteins for degradation by both the ubiquitin-proteasome system and the lysosomes. ${ }^{74}$ It was also observed to play a protective role in MPTP toxicity in a variety of models ${ }^{75-77}$ and is found in Lewy bodies. ${ }^{78,79}$ Of particular significance for the present study is the fact that $\mathrm{Hsc} 70$ also has a key role in the transport of specific proteins into mitochondria. ${ }^{78}$ As for most 
molecular chaperones, Hsc70 interaction with its substrates is dependent on ATP binding and several co-chaperones. One of these co-chaperones is STIP1 (or Hop), ${ }^{74}$ whose levels were also increased in the present model.

$\mathrm{T}$-complex protein 1 (TCP1 or CCT or TRiC) and Hsp60 are two different chaperone complexes that form the chaperonin family ( $60 \mathrm{kDa}$ heat shock protein complexes). Although they have similar chaperone functions, they differ in structure, where Hsp60 is composed of 14 identical subunits divided into two stacked rings and TCP1 is composed of at least 8 subunits that are encoded by unique genes. ${ }^{81}$ It was originally thought that they had specific and distinct subcellular locations with TCP1 in the cytosol and Hsp60 in the mitochondria. ${ }^{81}$ However, it has recently been shown that there is a functional $\mathrm{Hsp} 60$ pool in the cytoplasm too, ${ }^{82}$ and the main difference between the two complex chaperonins is due to substrate specificity. ${ }^{81}$ Mitochondrial Hsp60 plays an important role in the folding of mitochondrial proteins following their entry into the organelle. Hsp60 has previously been observed to be affected in a variety of neurodegenerative conditions and is up-regulated in a number of PD models. ${ }^{32,80}$ The presence of the particular TCP $1-\varepsilon$ subunit in the mitochondrial fraction and the significance of the change in levels following MPTP have yet to be investigated.

Endoplasmic resident protein 29 (ERp29) can be found in the ER lumen where it is thought to have a role in protein unfolding, adding disulfide bonds to proteins, assisting protein transport and secretion of mature proteins. ${ }^{83,84}$ A decrease in ERp29 protein levels in mitochondria following MPTP treatment was observed; whether this is due to a decrease in mitochondria-ER interactions or a decrease in total cellular ERp29 levels is not known.

\section{Mitofilin}

Mitofilin is an IMM protein with a peptide tail in the intermembrane space. ${ }^{83,85}$ Mitofilin knockdown studies in human HeLa cells showed that it had a role in cristae structure that led to increased biogenesis of IMM with no cristae junctions, which was thought to up-regulate ion flux, increase ROS production, increase mitochondrial potential and impair the process of oxidative phosphorylation, ${ }^{86}$ all of which have also been observed in MPTP-induced models. ${ }^{87,88}$ Recently, Weihofen and colleagues $^{89}$ found that mitofilin was one of the proteins interacting with PINK1, a mitochondrial protein kinase known to be disrupted in $\mathrm{PD},{ }^{90}$ linking mitochondrial morphology alteration with PINK1-mutation models. ${ }^{89}$ It has also previously been reported that dopamine-induced oxidative stress led to decreased mitofilin levels ${ }^{91}$ and covalently modified protein, ${ }^{92}$ further linking oxidative stress and mitofilin protein. The decreased levels of mitofilin observed in the present study may then reflect the oxidative stress induced by complex I inhibition. 88

\section{VDAC1}

VDAC1, a voltage-gated channel located in the outer mitochondrial membrane, was also up-regulated following MPTP treatment. Interestingly, VDAC 1 is involved in the regulation of cellular pathways that are affected in PD. ${ }^{93-96}$ First, it has a role in calcium, $\mathrm{NADH}$ reoxidation and glutamate homeostasis through its function as a channel and having affinity for these molecules. ${ }^{93,94}$ It has also been found to play a role in cell death by interacting with apoptotic molecules ${ }^{95,97}$ and is a target of several signaling kinases. ${ }^{93,96}$ A link between VDAC and complex I inhibition was recently made by Xiong and colleagues ${ }^{98}$ where VDAC protein and mRNA levels were observed to be elevated following rotenone-induced toxicity in Human SH-SY5Y neuronal cells. ${ }^{98}$ The present study showed that another complex I inhibitor, MPTP, also modulated VDACl protein levels, and that this occurred prior to neuronal death. It would therefore appear that VDAC1 up-regulation is a potential early marker of MPTPinduced cell death. Moreover, Lessner and colleagues ${ }^{99}$ found that VDAC1 levels were increased in striatal extracts in a 6-OHDA-hemiparkinsonian rat model of PD while Perriquet and colleagues ${ }^{24}$ reported that VDAC1 levels increased in the striatum and cortex of Parkin knockdown mice (used as a genetic model of PD). Finally, VDAC1 has recently been reported to be necessary for PINK1/Parkin-directed autophagy of damaged mitochondria. ${ }^{100}$ Thus, changes in VDAC may have a wider significance than previously thought in PD. In the present study, up to four different spots with different isoelectric points were detected using 2D-blot analysis, showing that the protein can exhibit multiple post-translational modifications, which could influence VDAC1 function following MPTP treatment.

\section{CONCLUSIONS}

The present study showed that several cellular pathways were affected by MPTP-induced toxicity prior to cell death. This has provided a more specific molecular insight into the pathways that are initially affected following complex I impairment. Up-regulation of several chaperone proteins in MPTP treated cells was observed, suggesting a link between metabolic changes due to complex 1 inhibition and protein folding. Similarly, extra-mitochondrial proteins, most of them known to be able to associate with mitochondria, were also affected following mitochondrial impairment showing that the insult was spreading to the rest of the cell. It is suggested here that VDAC1, a multifunction outer mitochondrial membrane, could have a key role in signaling between mitochondria and the rest of the cell. It could also be considered as a subcytotoxic biomarker of imminent cell death and we propose that further study should be undertaken to establish the precise role of VDAC in PD-linked cell death. Since complex 1 dysfunction is a biochemical characteristic described in Parkinson's disease, we believe that our work provides new important information of relevance to this condition.

\section{ASSOCIATED CONTENT}

S Supporting Information

2DE stained with SyproRuby showing spots identified following peptide mass fingerprinting; protein identification of spots from $2 \mathrm{DE}$; peptide mass fingerprinting of differentially expressed identified spots; relative distribution of subcellular markers expressed as sum of fractions following MPTP treatment compared to controls. This material is available free of charge via the Internet at http://pubs.acs.org.

\section{AUTHOR INFORMATION}

Corresponding Author

*Prof. E. Ellen Billett, School of Science and Technology, Nottingham Trent University, Clifton Lane, NG11 8NS Nottingham, U.K. Phone: 0044 (0)115 848 6356. Fax: + 441158486616. E-mail: ellen. billett@ntu.ac.uk.

\section{ACKNOWLEDGMENT}

The authors would like to thank Dr. David Boocock for his technical assistance with the MALDI-TOF mass spectrometer. 


\section{ABBREVIATIONS}

2DE , 2-dimensional-gel electrophoresis; ACN , acetonitrile; ATP synthase- $\alpha$, ATP synthase $\alpha$-subunit isoform 1 ; ATP synthase-d, ATP synthase subunit d; CHCA , $\alpha$-cyano-4-hydroxycinnamic acid; Cyt $c$, cytochrome c; dbcAMP, dibutryl adenosine $3^{\prime}, 5^{\prime}$ cyclic monophosphate; DMEM , Dulbecco's Modified Eagle Medium; DTT , dithiothreitol; EB , extraction buffer; ECHM , enoylCoA hydratase mitochondrial; ECL, enhanced chemiluminescence; ENOA , $\alpha$-enolase; ERP29, endoplasmic reticulum resident protein 29; ETC, electron transfer chain; ETF $\alpha$, electron transfer flavoprotein subunit- $\alpha$; FMH , fumarase; GAPDH , glyceraldehyde-3-phosphate dehydrogenase; GOT2, glutamate oxaloacetate transaminase 2; HRP, horseradish peroxidase; $\mathrm{Hsc} 70$, heat shock cognate $71 \mathrm{kDa}$; Hsp60,60 kDa heat shock protein; IEF , isoelectrofocusing; IMM, inner mitochondrial membrane; LAMP2, lysosomal-associated membrane protein 2; LC-MS , liquid chromatography-mass spectrometry; LDH, lactate dehydrogenase; MALDI-TOF , matrix-assisted laser desorption/ionization-time-of-flight; $\mathrm{MAO}$, monoamine oxidase; $\mathrm{MDH}$, malate dehydrogenase; MPP+ , 1-methyl-4-phenylpyrimidium; MPTP , 1-methyl-4-phenyl-1,2,3,6-tetrahydropyridine; MTT ， 3-(4,5-dimethylthiazol-2-yl)-2,5-diphenyltetrazolium bromide; $\mathrm{NADPH}$, nicotinamide adenine dinucleotide phosphate; OMM, outer mitochondrial membrane; $\mathrm{PD}$, Parkinson's disease; $\mathrm{pI}$, isoelectric point; PINK1, phosphatase and tensin homologue-induced putative kinase 1; SCOT1, succinyl-CoA:3-ketoacid-coenzyme A transferase 1; $\mathrm{SDH}$, succinate dehydrogenase; SDS-PAGE , sodium dodecyl-sulfate-polyacrylamide gel electrophoresis; STIP1 , stress-induced protein 1; TE , total extract; TCPE , T-complex protein 1 subunit epsilon; VDAC, voltage-dependent-anion channel

\section{REFERENCES}

(1) Palacino, J. J.; Sagi, D.; Goldberg, M. S.; Krauss, S.; Motz, C.; Wacker, M.; Klose, J.; Shen, J. J. Biol. Chem. 2004, 279 (18), $18614-18622$

(2) Thomas, B.; Beal, M. F. Hum. Mol. Genet. 2007, 16 (2), R183-194.

(3) Lane, E. L.; Handley, O. J.; Rosser, A. E.; Dunnett, S. B. Neuropsychiatr. Dis. Treat. 2008, 4 (5), 835-845.

(4) Olanow, C. W.; Tatton, W. G. Annu. Rev. Neurosci. 1999, $22,123-144$.

(5) Olanow, C. W.; Perl, D. P.; DeMartino, G. N.; McNaught, K. S. Lancet Neurol. 2004, 3 (8), 496-503.

(6) Leung, H.; Mok, V. Hong Kong Med. J. 2005, 11 (6), 476-489.

(7) Winklhofer, K. F.; Haass, C. Biochim. Biophys. Acta 2010, 1802 (1), 29-44.

(8) McNaught, K. S.; Jenner, P. Neurosci. Lett. 2001, 297 (3), 191-194.

(9) Barzilai, A.; Melamed, E. Trends Mol. Med. 2003, 9 (3), 126-132. (10) McGeer, P. L.; McGeer, E. G. Alzheimer Dis. Assoc. Disord. 1998, 12 (2), S1-6.

(11) Adams, J. D., Jr.; Odunze, I. N. Biochem. Pharmacol. 1991, 41 (8), 1099-1105.

(12) Wullner, U.; Loschmann, P. A; Schulz, J. B.; Schmid, A; Dringen, R.; Eblen, F.; Turski, L.; Klockgether, T. NeuroReport 1996, $7(4), 921-923$.

(13) Schapira, A. H.; Cooper, J. M.; Dexter, D.; Clark, J. B.; Jenner, P.; Marsden, C. D. J. Neurochem. 1990, 54 (3), 823-827.

(14) Cardoso, S. M.; Moreira, P. I.; Agostinho, P.; Pereira, C.; Oliveira, C. R. Curr. Drug Targets CNS Neurol. Disord. 2005, 4 (4), $405-419$.

(15) Fitzgerald, J. C.j Plun-Favreau, H. FEBS J. 2008, 275 (23), $5758-5766$
(16) Davis, G. C.; Williams, A. C.; Markey, S. P.; Ebert, M. H.; Caine, E. D.; Reichert, C. M.; Kopin, I. J. Psychiatry Res. 1979, 1 (3), 249-254.

(17) Brooks, W. J.; Jarvis, M. F.; Wagner, G. C. J. Neural Transm. 1989, $76(1), 1-12$.

(18) Nicklas, W. J.; Vyas, I.; Heikkila, R. E. Life Sci. 1985, 36 (26), 2503-2508.

(19) Ramsay, R. R.; Salach, J. I.; Singer, T. P. Biochem. Biophys. Res. Commun. 1986, 134 (2), 743-748.

(20) Tetrud, J. W.; Langston, J. W. Neurology 1992, 42 (2), 407-410.

(21) Przedborski, S.; Jackson-Lewis, V.; Naini, A. B.; Jakowec, M.; Petzinger, G.; Miller, R; Akram, M. J. Neurochem. 2001, 76 (5), 1265-1274.

(22) Xun, Z.; Sowell, R. A.; Kaufman, T. C.; Clemmer, D. E. J. Proteome Res. 2007, 6 (1), 348-357.

(23) Xun, Z.; Sowell, R. A.; Kaufman, T. C.; Clemmer, D. E. Mol. Cell. Proteomics 2008, 7 (7), 1191-1203.

(24) Periquet, M.; Corti, O.; Jacquier, S.; Brice, A. J. Neurochem. 2005, 95 (5), 1259-1276.

(25) Poon, H. F.; Frasier, M.; Shreve, N.; Calabrese, V.; Wolozin, B.; Butterfield, D. A Neurobiol. Dis. 2005, 18 (3), 492-498.

(26) Davison, E. J.; Pennington, K.; Hung, C. C.; Peng, J.; Rafiq, R.; Ostareck-Lederer, A.; Ostareck, D. H.; Ardley, H. C.; Banks, R. E.; Robinson, P. A. Proteomics 2009, 9 (18), 4284-4297.

(27) Zhao, X.; Li, Q.; Zhao, L.; Pu, X. Proteomics: Clin. Appl. 2007, 1 (12), 1559-1569.

(28) Chin, M. H.; Qian, W. J.; Wang, H.; Petyuk, V. A.; Bloom, J. S.; Sforza, D. M.; Lacan, G.; Liu, D.; Khan, A. H.; Cantor, R M.; Bigelow, D. J.; Melega, W. P.; Camp, D. G., II; Smith, R. D.; Smith, D. J. J. Proteome Res. 2008, 7 (2), 666-677.

(29) Zhang, X.; Zhou, J. Y.; Chin, M. H.; Schepmoes, A. A.; Petyuk, V. A.; Weitz, K. K.; Petritis, B. O.; Monroe, M. E.; Camp, D. G.; Wood, S. A.; Melega, W. P.; Bigelow, D. J.; Smith, D. J.; Qian, W. J.; Smith, R. D. J. Proteome Res. 2010, 9 (3), 1496-1509.

(30) Xie, H.; Chang, M.; Hu, X.; Wang, D.; Tian, M.; Li, G.; Jiang, H.; Wang, Y.; Dong, Z.; Zhang, Y.; Hu, L. Neurol. Sci. 201010.1007/ s10072-010-0340-3.

(31) Xun, Z.; Kaufman, T. C.; Clemmer, D. E. J. Proteome Res. 2009, $8(10), 4500-4510$.

(32) Jin, J.; Hulette, C.; Wang, Y.; Zhang, T.; Pan, C.; Wadhwa, R.; Zhang, J. Mol. Cell. Proteomics 2006, 5 (7), 1193-1204.

(33) Pennington, K; Peng, J.; Hung, C. C.; Banks, R. E.; Robinson, P. A. J. Proteome Res. 2010, 9 (5), 2390-2401.

(34) Jin, J.; Meredith, G. E.; Chen, L.; Zhou, Y.; Xu, J.; Shie, F. S.; Lockhart, P.; Zhang, J. Brain Res. Mol. Brain Res. 2005, 134 (1), 119-138. (35) Jin, J.; Davis, J.; Zhu, D.; Kashima, D. T.; Leroueil, M.; Pan, C.; Montine, K. S.; Zhang, J. BMC Neurosci. 2007, 8, 67.

(36) Deumens, R.; Blokland, A.; Prickaerts, J. Exp. Neurol. 2002, 175 (2), 303-317.

(37) Cappelletti, G.; Pedrotti, B.; Maggioni, M. G.; Maci, R. Cell Biol. Int. 2001, 25 (10), 981-984.

(38) Jin, J.; Li, G. J.; Davis, J.; Zhu, D.; Wang, Y.; Pan, C.; Zhang, J. Mol. Cell. Proteomics 2007, 6 (5), 845-859.

(39) Augusti-Tocco, G.; Sato, G. Proc. Natl. Acad. Sci. U.S.A. 1969, 64 (1), 311-315.

(40) Narotzky, R; Bondareff, W. J. Cell Biol. 1974, 63 (1), 64-70.

(41) Prashad, N.; Rosenberg, R. N. Biochim. Biophys. Acta 1978, 539 (4), 459-469.

(42) De Girolamo, L. A.; Billett, E. E.; Hargreaves, A. J. J. Neurochem. 2000, 75 (1), 133-140.

(43) Harris, W.; Munoz, D.; Bonner, P. L.; Hargreaves, A. J. Toxicol. In. Vitro. 2009, $23(8), 1559-1563$.

(44) Flaskos, J.; McLean, W. G.; Fowler, M. J.; Hargreaves, A. J. Neurosci. Lett. 1998, 242 (2), 101-104.

(45) Zhou, X. W.; Winblad, B.; Guan, Z.; Pei, J. J. J. Alzheimer's Dis. 2009, 17 (4), 929-937.

(46) Ye, C.; Zhang, Y.; Wang, W.; Wang, J.; Li, H. Neurosci. Lett. 2008, $442(1), 63-68$.

(47) Amazzal, L.; Lapotre, A.; Quignon, F.; Bagrel, D. Neurosci. Lett. $2007,418(2), 159-164$. 
(48) De Girolamo, L. A.; Hargreaves, A. J.; Billett, E. E. J. Neurochem. 2001, 76 (3), 650-660.

(49) Lee, Y. M.; Park, S. H.; Chung, K. C.; Oh, Y. J. Neurosci. Lett. 2003, 352 (1), 17-20.

(50) Mosmann, T. J. Immunol. Methods 1983, 65 (1-2), 55-63.

(51) Lai, J. C.; Clark, J. B. Methods Enzymol. 1979, 55, 51-60.

(52) Bradford, M. M. Anal. Biochem. 1976, 72, $248-254$.

(53) Laemmli, U. K. Nature 1970, 227 (5259), 680-685.

(54) Towbin, H.; Staehelin, T.; Gordon, J. Proc. Natl. Acad. Sci. U.S. A. 1979, 76 (9), 4350-4354.

(55) Wu, E. Y.; Smith, M. T.; Bellomo, G.; Di Monte, D. Arch. Biochem. Biophys. 1990, 282 (2), 358-362.

(56) Di Monte, D.; Jewell, S. A.; Ekstrom, G.; Sandy, M. S.; Smith, M. T. Biochem. Biophys. Res. Commun. 1986, 137 (1), 310-315.

(57) Scheffler, N. K.; Miller, S. W.; Carroll, A. K.; Anderson, C.; Davis, R. E.; Ghosh, S. S.; Gibson, B. W. Mitochondrion 2001, 1 (2), $161-179$.

(58) Grover, G. J.; Marone, P. A.; Koetzner, L.; Seto-Young, D. Int.J. Biochem. Cell Biol. 2008, 40 (12), 2698-2701.

(59) Basso, M.; Giraudo, S.; Corpillo, D.; Bergamasco, B.; Lopiano, L.; Fasano, M. Proteomics 2004, 4 (12), 3943-3952.

(60) Chalmers-Redman, R. M.; Fraser, A. D.; Carlile, G. W.; Pong, A; Tatton, W. G. Biochem. Biophys. Res. Commun. 1999, 257 (2), $440-447$.

(61) Storch, A.; Kaftan, A.; Burkhardt, K.; Schwarz, J. Brain Res. 2000, 855 (1), 67-75.

(62) Mazzio, E.; Soliman, K. F. Neurotoxicology 2003, 24 (1), $137-147$.

(63) Villa, R. F.; Arnaboldi, R.; Ghigini, B.; Gorini, A. Neurochem. Res. 1994, 19 (3), 229-236.

(64) McKenna, M. C.; Stevenson, J. H.; Huang, X.; Hopkins, I. B. Neurochem. Int. 2000, 37 (2-3), 229-241.

(65) Lange, K. W.; Kornhuber, J.; Riederer, P. Neurosci. Biobehav. Rev. 1997, 21 (4), 393-400.

(66) Meredith, G. E.; Totterdell, S.; Beales, M.; Meshul, C. K. Exp. Neurol. 2009, 219 (1), 334-340.

(67) Tieu, K.; Perier, C.; Caspersen, C.; Teismann, P.; Wu, D. C.; Yan, S. D.; Naini, A. Vila, M.; Jackson-Lewis, V.; Ramasamy, R.; Przedborski, S. J. Clin. Invest. 2003, 112 (6), 892-901.

(68) Imamura, K.; Takeshima, T.; Kashiwaya, Y.; Nakaso, K.; Nakashima, K. J. Neurosci. Res, 2006, 84 (6), 1376-1384.

(69) Gregersen, N.; Bross, P. Methods Mol. Biol. 2010, 648, 3-23.

(70) Fornai, F.; Schluter, O. M.; Lenzi, P.; Gesi, M.; Ruffoli, R; Ferrucci, M.; Lazzeri, G.; Busceti, C. L.; Pontarelli, F.; Battaglia, G.; Pellegrini, A.; Nicoletti, F.; Ruggieri, S.; Paparelli, A.; Sudhof, T. C. Proc. Natl. Acad. Sci. U.S.A. 2005, 102 (9), 3413-3418.

(71) Casoni, F.; Basso, M.; Massignan, T.; Gianazza, E.; Cheroni, C.; Salmona, M.; Bendotti, C.; Bonetto, V. J. Biol. Chem. 2005, 280 (16), $16295-16304$.

(72) Magi, B.; Ettorre, A.; Liberatori, S.; Bini, L.; Andreassi, M.; Frosali, S.; Neri, P.; Pallini, V.; Di Stefano, A. Cell Death Differ. 2004, 11 (8), 842-852.

(73) Takano, M.; Otani, M.; Sakai, A; Kadoyama, K.; Matsuyama, S.; Matsumoto, A.; Takenokuchi, M.; Sumida, M.; Taniguchi, T. NeuroReport 2009, 20 (18), 1648-1653.

(74) Meimaridou, E.; Gooljar, S. B.; Chapple, J. P. J. Mol. Endocrinol. 2009, 42 (1), 1-9.

(75) Freyaldenhoven, T. E.; Ali, S. F. Brain Res. 1996, 735 (1), 42-49.

(76) Quigney, D. J.; Gorman, A. M.; Samali, A. Brain Res. 2003, 993 $(1-2), 133-139$.

(77) Donaire, V.; Niso, M.; Moran, J. M.; Garcia, L.; Gonzalez-Polo, R A.; Soler, G.; Fuentes, J. M. Brain Res. Bull. 2005, 67 (6), 509-514.

(78) Young, J. C.; Hoogenraad, N. J.; Hartl, F. U. Cell 2003, 112 (1), $41-50$

(79) Auluck, P. K; Chan, H. Y.; Trojanowski, J. Q.; Lee, V. M.; Bonini, N. M. Science 2002, 295 (5556), 865-868.

(80) Barzilai, A.; Zilkha-Falb, R.; Daily, D.; Stern, N.; Offen, D.; Ziv, I.; Melamed, E.; Shirvan, A. J. Neural Transm. Suppl. 2000, 60, 59-76.
(81) Fink, A. L. Physiol. Rev. 1999, 79 (2), 425-449.

(82) Itoh, H.; Komatsuda, A; Ohtani, H.; Wakui, H.; Imai, H.; Sawada, K.; Otaka, M.; Ogura, M.; Suzuki, A.; Hamada, F. Eur. J. Biochem. 2002, 269 (23), 5931-5938.

(83) Odgren, P. R.; Toukatly, G.; Bangs, P. L.; Gilmore, R.; Fey, E. G. J. Cell. Sci. 1996, 109 (9), 2253-2264.

(84) Barak, N. N.; Neumann, P.; Sevvana, M.; Schutkowski, M.; Naumann, K.; Malesevic, M.; Reichardt, H.; Fischer, G.; Stubbs, M. T.; Ferrari, D. M. J. Mol. Biol. 2009, 385 (5), 1630-1642.

(85) Gieffers, C.; Korioth, F.; Heimann, P.; Ungermann, C.; Frey, J. Exp. Cell Res. 1997, 282 (2), 395-399.

(86) John, G. B.; Shang, Y.; Li, L.; Renken, C.; Mannella, C. A.; Selker, J. M.; Rangell, L.; Bennett, M. J.; Zha, J. Mol. Biol. Cell 2005, 16 (3), 1543-1554.

(87) Song, X.; Perkins, S.; Jortner, B. S.; Ehrich, M. Neuro Toxicology 1997, 18 (2), 341-353.

(88) Blum, D.; Torch, S.; Lambeng, N.; Nissou, M.; Benabid, A. L.; Sadoul, R; Verna, J. M. Prog. Neurobiol. 2001, 65 (2), 135-172.

(89) Weihofen, A.; Thomas, K J.; Ostaszewski, B. L.; Cookson, M. R.; Selkoe, D. J. Biochemistry 2009, 48 (9), 2045-2052.

(90) Valente, E. M.; Abou-Sleiman, P. M.; Caputo, V.; Muqit, M. M.; Harvey, K.; Gispert, S.; Ali, Z.; Del Turco, D.; Bentivoglio, A. R.; Healy, D. G.; Albanese, A.; Nussbaum, R.; Gonzalez-Maldonado, R.; Deller, T.; Salvi, S.; Cortelli, P.; Gilks, W. P.; Latchman, D. S.; Harvey, R. J.; Dallapiccola, B.; Auburger, G.; Wood, N. W. Science 2004, 304 (5674), $1158-1160$.

(91) Van Laar, V. S.; Dukes, A. A; Cascio, M.; Hastings, T. G. Neurobiol. Dis. 2008, 29 (3), 477-489.

(92) Van Laar, V. S.; Mishizen, A. J.; Cascio, M.; Hastings, T. G. Neurobiol. Dis. 2009, 34 (3), 487-500.

(93) Hajnoczky, G.; Csordas, G.; Yi, M. Cell Calcium 2002, 32 (56), 363-377.

(94) Lemasters, J. J.; Holmuhamedov, E. Biochim. Biophys. Acta 2006, 1762 (2), 181-190.

(95) Vyssokikh, M. Y.; Brdiczka, D. Acta Biochim. Pol. 2003, 50 (2), $389-404$.

(96) Das, S.; Wong, R.; Rajapakse, N.; Murphy, E.; Steenbergen, C. Circ. Res. 2008, 103 (9), 983-991.

(97) Tsujimoto, Y.; Shimizu, S. Biochimie 2002, 84 (2-3), 187-193.

(98) Xiong, Y.; Ding, H.; Xu, M.; Gao, J. Neurochem. Res. 2009, 34 (4), 746-754.

(99) Lessner, G.; Schmitt, O.; Haas, S.; Mikkat, S.; Kreutzer, M.; Wree, A; Glocker, M. I. Proteome Res, 2010, 9, 4761-4787.

(100) Geisler, S.; Holmström, K M.; Skujat, D.; Fiesel, F. C.; Rothfuss, O. C.; Kahle, P. J.; Springer, W. Nat. Cell Biol. 2010, 12 (2), 119-31. 